Portland State University

PDXScholar

6-13-1975

\title{
The American President as Legislative Leader: Historical Development of the Role
}

Patricia Mathews Walhood

Portland State University

Follow this and additional works at: https://pdxscholar.library.pdx.edu/open_access_etds

Part of the Political History Commons, and the United States History Commons Let us know how access to this document benefits you.

\section{Recommended Citation}

Walhood, Patricia Mathews, "The American President as Legislative Leader: Historical Development of the Role" (1975). Dissertations and Theses. Paper 2438.

https://doi.org/10.15760/etd.2435

This Thesis is brought to you for free and open access. It has been accepted for inclusion in Dissertations and Theses by an authorized administrator of PDXScholar. Please contact us if we can make this document more accessible: pdxscholar@pdx.edu. 
AN ABSTRACT OF THE THESIS OF Patricia Mathews Walhood for the Master of Science in Teaching presented May 16, 1975.

Title: The American President as Legislative Leader - Historical

Development of the Role

APPROVED BY MEMBERS OF THE THESIS COMMITTEE:
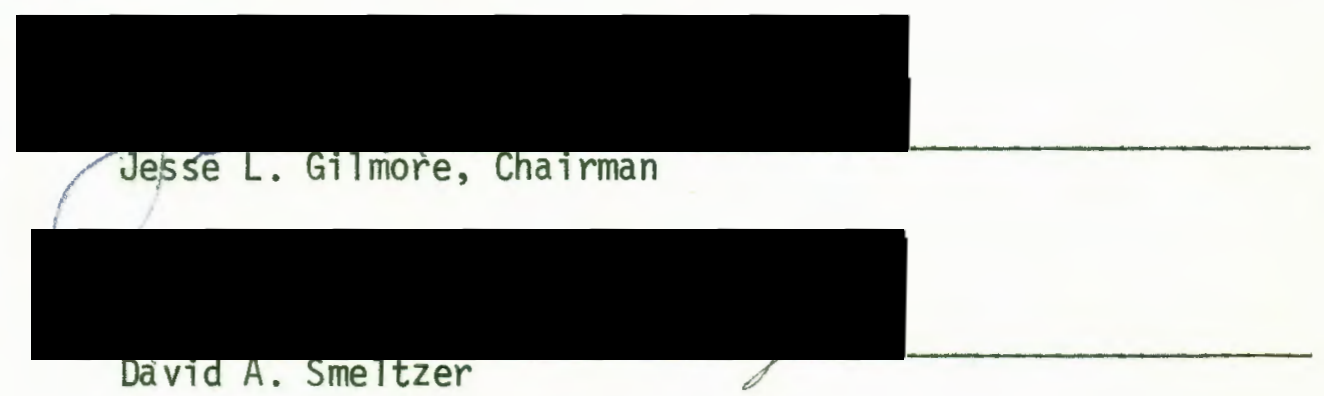

David A. Sme ltzer

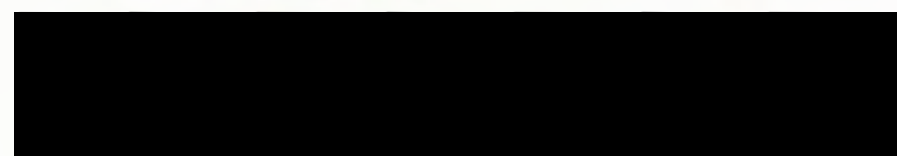

Forbes W. WiTtiams

This thesis seeks to define the American President's role as legislative leader and to trace the origin and development of that role throughout the history of the office of the presidency. Presidents were not consistently active in this capacity until the middle of the twentieth century.

The first part of the thesis examines precedents set by strong presidents prior to and early in the twentieth century, as well as an important institutional change in the government, the creation of the Budget System, which smoothed the way for Presidential adoption of the tasks of legislative leader.

The middle sections of the work examine the three American Presidents who fully adopted and institutionalized the role of legislative 
leader within the presidency, Franklin Roosevelt, Harry Truman and Dwight Eisenhower.

Finally, the conclusions section examines the implications of presidential adoption of this role in the American system of government with respect to the balance between the President and the Congress.

Research for this paper consisted of careful examination of primary sources, books and periodicals covering the history of the presidency, as well as examination of political commentary on the office and many of $i$ ts occupants. In addition, communication with the Office of Legislative Reference in the Executive Office of the President provided helpful information. 
The American President as Legislative Leader Historical Development of the Role

by

PATRICIA MATHEWS WALHOOD

A thesis submitted in partial fulfillment of the requirements for the degree of

\author{
MASTER OF SCIENCE \\ in \\ TEACHING
}

Portland State University

1975 
TO THE OFFICE OF GRADUATE STUDIES AND RESEARCH:

The members of the Committee approve the thesis of

Patricia Mathews Walhood presented May 16, 1975.

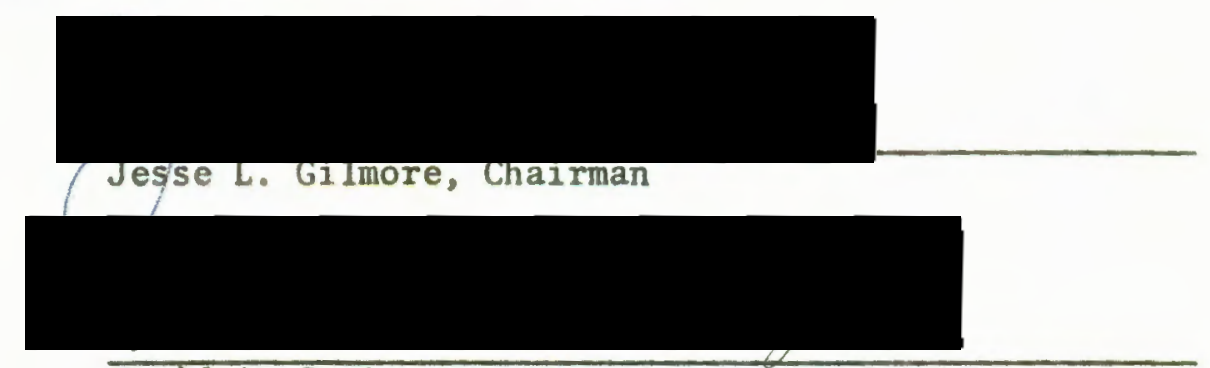

David A. Smeltzer

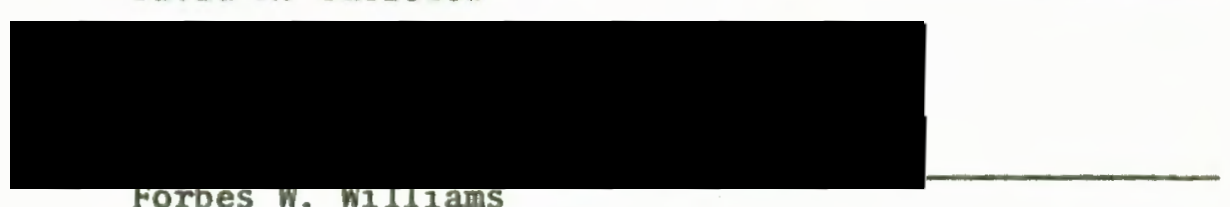

APPROVED :
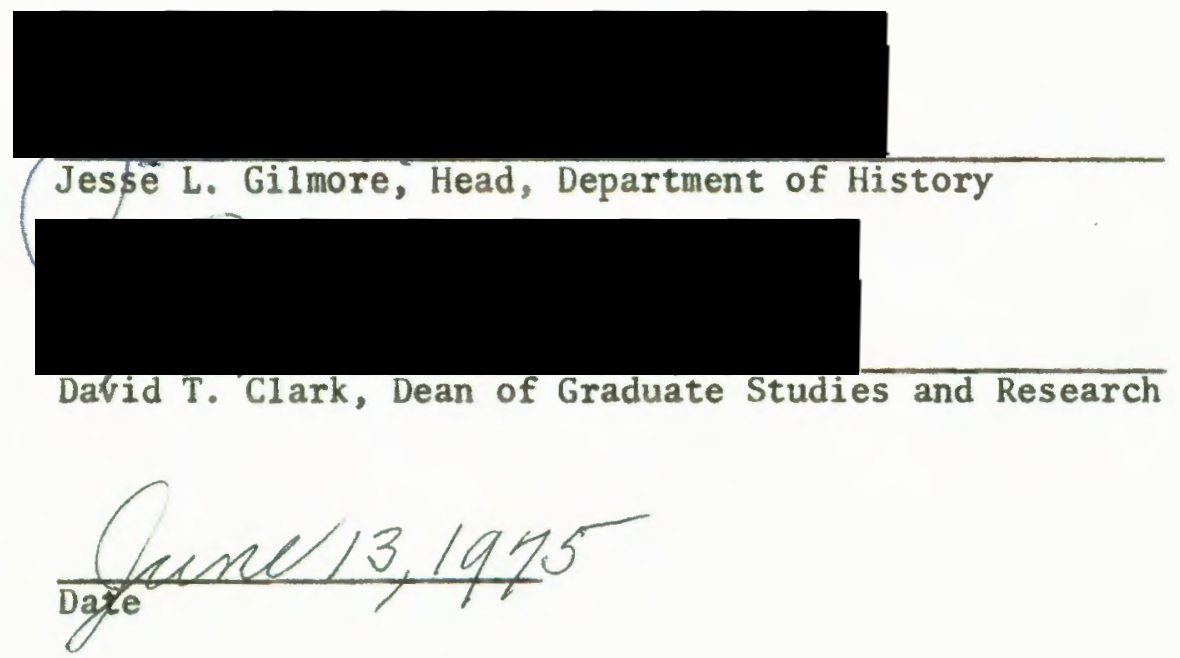


\section{ACKNOWLEDGMENTS}

Acknowledgments are extended to Dr. Jesse Gilmore, Chairman of the Thesis Committee. His considerable expertise in the field of American History and his continued encouragement were of immeasurable assistance to me.

Appreciation is also extended to Dr. David Smeitzer, whose class on the Presidency served as the genesis for this research. His interest in the Presidency and hopefully his high standards of scholarship are reflected in this work.

Special appreciation is extended to Dr. Forbes Williams whose support and encouragement throughout the course of my graduate work have been invaluable. In addition, his varied background and interest in Political Science were of much help in the preparation of this thesis.

A special word of thanks is extended to Ms. Betty Wilhelm for typing this work. Without her assistance, completion of this work would not have been possible.

Finally, appreciation is expressed to my family for their patience and support over the past four years. 
TABLE OF CONTENTS

PAGE

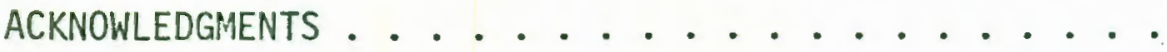

CHAPTER

I INTRODUCTION. ..............

II HISTORICAL BACKGROUND ........... 5

Central Planning of the Program ..... 5

Drafting of Legislation in the Executive Branch. .......... 7

Maneuvering by Executive Branch to Secure Passage of Favored Measures ...

8

Direct Presidential Appeal on Behalf of Measures--To Congress and the

Public. .......... 20 20

II ESTABLISHMENT OF THE BUDGET BUREAU. . . . . . 24

IV FDR AS LEGISLATIVE LEADER . . . . . . . 31

Central Planning of the Legislative

Program ............ 32

Drafting of Legislation in the Executive

Branch. . ........

Maneuvering by the Executive Branch to

Secure Passage of Favored

Measures..........

Direct Appeal on Behalf of Measures--To

Congress and the Public.....

Roosevelt As Leader of Legislation: The

Fair Labor Standards Act. ..... 41

Roosevelt As Leader of Legislation: Lend Lease .......... 
y THE TRUMAN ADMINISTRATION ......... 49

Central Planning of a Program and Drafting Measures in the Executive Branch. .

Maneuvering by the Executive Branch to Secure Passage of Favored

Measures. . . . . . . . .

Direct Appeal on Behalf of Measures--To

Congress and to the Public....

Truman as Leader of Legislation--The Marshall Plan ..........

VI DWIGHT DAVID EISENHOWER . . . . . . . . .

Centrat Planning of the Legislative Program ............

Drafting Legislation in the Executive Branch............

Maneuvering by the Executive to Pass

Fayored Measures. . . . . . .

Direct Appeal on Behalf of Measures--To

Congress and to the Public. ...

Eisenhower as Legislative Leader--The Civil Rights Act of 1957...... 71

VII CONCLUSIONS . . . . . . . . . . . . 76

BIBLIOGRAPHY. . . . . . . . . . . . . . . . 81

APPENDIX. . . . . . . . . . . . . . . . . 88 


\section{CHAPTER I}

\section{INTRODUCTION}

The Constitution set the stage for the emergence of the President as initiator of legislative action within the American system of government with this clause: "He shall from time to time give to the Congress Information of the State of the Union, and recommend to their consideration such measures as he shall judge necessary and expedient." 1 The role of legislative leader was not assumed to any great extent by presidents until well into the twentieth century. However, throughout the history of the presidency strong executives have set precedents in this area. During the presidency of Frank 7 in D. Roosevelt, the legislative leader role was not only assumed, but came to be an integral part of the institution of the presidency -- so much so that since then the President has been expected to perform it, as one presidential scholar, Herman Finer, has pointed out:

- . . The nation has come to expect of the president not only proposals for law and financing but a veritable program, an integrated, well-concerted set of blueprints for the nation's progress and security. . . When important issues are at stake, congressmen look to the president for a program of legislation: and they blame him vociferously if he does not act in this wise. - Most concern themselves with legislation involving the districts they represent and in most other matters expect the president to formulate and promote national policy. ${ }^{2}$

1. Constitution of the United States, Article 2, Section 3.

2. Herman Finer, The Presidency: Crisis and Regeneration, (Chicago, University of Chicago Press, 1960), 67. 
This set of expectations marks a distinct departure from the nineteenth century model, when it was considered the prerogative of Congress to initiate all legislation. Recent presidents who have attempted to return to this old model and have failed to perform as legislative leader have met with strong criticism. President Eisenhower, upon taking office in 1953, did not provide a legislative agenda for Congress. He considered that to do so was a "Democratic usurpation of Congress" prerogative, but his Republican legislature disagreed. Thereafter, he presented an annual legislative program." 3

The growth of the president's role as chief legislator has hinged upon a number of factors and developments. As Clinton Rossiter pointed out in his book on the presidency:

When Congress finaliy gave up primary responsibility for preparing the budget in 1921, it had no choice but to call on the President to come to the rescue. By abdicating an ancient function it could no longer perform, it gave a tremendous boost to the power of the President, not only to control his administration, but to influence the legislative process. ${ }^{4}$

A second factor in the development of the role of legislative leader has been the vast growth of the Federal government and the increasing complexity and volume of the problems with which it must deal. The increasingly difficult problems the Congress is asked to solve have made external leadership a necessary part of effective operation. "The President alone is in a political, Constitutional and practical position to

3. Dorothy Buckton James, The Contemporary Presidency (New York, Western Pub7ishing Company, Inc., 1969), 77.

4. Clinton Rossiter, The American Presidency (New York, Harcourt, Brace and Company, 1956), 65. 
provide such 7eadership." 5

Hand in hand with this increased complexity has come vast growth and reorganization within the executive branch of government. This has not only facilitated the President's adoption of the role of legislative leader but has actually in many instances institutionalized it. For the purpose of this paper the author will consider the period of vast expansion and increased complexity as beginning with the Presidency of Franklin D. Roosevelt. The two presidents immediately following Roosevelt, Truman and Eisenhower, built upon the base established by FDR, further entrenching the role of chief legislator within the institutional framework of the Presidency.

Historical background and precedents prior to the era of Roosevelt will be briefly sketched in the first chapter. The second will deal with the establishment of the Budget Bureau in 1921 which helped to set the stage for the emergence of Frank 1 in Roosevelt as a strong legislative Teader.

The third chapter will deal with the Roosevelt years, and the fourth and fifth with the two presidents immediately following FDR. The final chapter will draw conclusions concerning the assumption of the role of Tegislative leader by the American President and the institutionalization of that role.

For the sake of clarification, this role of legislative leader will be divided into several functions which are supportive of the legislative process. These include 1) central planning of the President's legislative

5. Clinton Rossiter, The American Presidency (New York, Harcourt, Brace and Company, 1956), 14. 
program, normally centered in the Office of Legislative Reference of the Office of Management and the Budget; 2) actual drafting of bills within the executive branch; 3) political maneuvering of various sorts to push administration measures through Congress--this may include patronage, party maneuvering by the President, the use of legislative specialists in the executive branch to guide measures along, and threatened or actual use of veto power- $;, 4$ ) and finally; direct Presidential appeal on behalf of favored measures. Such appeal may be in the form of special messages to Congress, often delivered-in person, as well as appeals for support directly to the public through the use of the media. 


\section{HISTORICAL BACKGROUND}

By examining each of the four legislative functions of the executive in turn and considering in part how they were, or were not, assumed by various Presidents prior to Franklin Roosevelt it should be possible to obtain an idea of the historical foundation upon which the modern role of the President as leader in legislation is built.

\section{CENTRAL PLANNING OF THE PROGRAM}

Coordinated central planning of the executive's legislative program is a twentieth-century phenomenon, dependent in its development on both the creation of the Budget Bureau and the enlargement of the President's staff. However, this development was foreshadowed early in the history of the Presidency in the role played by Alexander Hamilton as the first Secretary of the Treasury.

The fllowing from an article published in 1889 sheds light on the attitude of Congress toward the Presidency in the nineteenth century, and in addition points up the early practices of Hamilton:

Under the early practice of our government, the Secretary of the Treasury occupied a position more nearly like that of an English Chancellor of the Exchequer than the present spirit of Congress would allow. The arrangements for securing his responsibility were defective, but the responsibility itself, not only for administration, but for guiding the course of legislation was recognized. The early communications of the Secretary to Congress often presented something like a budget, with a statement of the measures necessary for its working, and any new proposi- 
tion became a government measure. ${ }^{1}$

These activities certainly appear to be an early version of central planning. Actions of the nation's first Secretary of the Treasury foreshadowed the future enlargement of the executive branch as well. Hamilton supplied the Congress with numerous reports which did much to shape public policy. Considerable study and research went with the preparation of these reports--and Hamilton had no staff of assistants--the labor was his. His manuscripts contain much evidence of the extent of the work which went into his reports. ${ }^{2}$

One could assume that Alexander Hamilton, looking at the contemporary Presidency, would be neither as surprised nor as dismayed at what it has become as might others among his contemporaries.

In fact, after Washington's administration, Presidents did not present programs of desired legislation to the Congress in any organized sense. Strong Presidents such as Jefferson and Woodrow Wilson did exert pressures on Congress for passage of measures they favored, but it was not until well into the twentieth century that an organized system for developing a legislative proaram evolved, as Richard Neustadt points out in his study of the Presidency and legislation, the "comprehensive and specific inventory, . . .presented in detailed fashion and packaged form at the opening of each session of Congress" 3 is a recent phenomenon dating

1. Charles F. Dunbar, "Some Precedents Followed by Alexander Hamilton," Quarterly Journal of Economics, III (Cambridge, 1889), 32.

2. 0. R. McGuire, "Administrative Lawmaking," Annals of the American Academy of Political Science, Vol. 18 (May, 1936), 82.

3. Richard Neustadt, "The Presidency and Legislation: The Growth of Central Clearance, American Political Science Review, Vol. 48 (1954), 665. 
back only as far as the presidency of Harry Truman.

\section{DRAFTING OF LEGISLATION IN THE EXECUTIVE BRANCH}

This function once aga in was assumed in the administration of George Washington by Alexander Hamilton, who drafted many bills. One example, found in his letters and submitted in its final form with his Report to the House on Public Credit, is entitled: "Draft of an Act Imposing Certain Inland Duties on Foreign Wines." 4 In addition, Hamilton is credited with drafting the bill which established the Post Office. 5

Subsequent administrations under the influence of the Congress' jealousy regarding such matters were inactive in the realm of drafting legislation. The next president to vigorously pursue such activity was Woodrow Wilson. David Houston, who served as his Secretary of Agriculture, tells of the unique position of the Department with respect to drafting legislation. 6

David-Houston goes on to enumerate several such measures which were drafted by his department in the executive branch and later passed by the Congress, including the Agricultural Educational Extension Act, passed in 1914, the Grain Standards Act, the Farm Loan Act and the Federal Aid Road Act.

4. Harold C. Syrette and Jacob E. Cooke (Ed.), The Papers of Alexander Hamilton, VII, (New York, Columbia University Press, 1962), 138.

5. Ibid., 184.

6. David F. Houston, Eight Years With Wilson's Cabinet, I Garden City, Doubleday, Page and Company, 1962), 201. 
III. MANEUVERING BY EXECUTIVE BRANCH TO SECURE PASSAGE OF FAVORED MEASURES

Various types of political maneuvering and persuasion have been used by most strong Presidents, dating from the administration of George Washington. The type of tactic used depended both upon the man in office and the circumstances with which he dealt.

Washington's view of the Presidency included the fullest use of all of the powers granted the executive by the Constitution. This included control over the legislative process. As seen earlier in this chapter, his chief spokesman and advisor in this area was Hamilton--in a sense the first legislative "specialist" to be found in the executive branch--as is clearly shown in the following description of the passage of Hamilton's proposals for funding the national debt:

Only after the hardest kind of legislative struggle, indeed after seven months of mounting anger, four adverse votes in the House, and one memorable deal among Hamilton, Madison and Jefferson, were Hami 7 ton's proposals for funding the national debt and assuming state debts enacted into law. He had exerted every political skill he owned to produce this favorable result, and both his friends and enemies had been made aware of his commitment to the Union. . . William Maclay. . observed tartly a few months later: "Congress may go home. Mr. Hamilton is all-powerful and fails in nothing he attempts." While this was the exaggerated comment of a bitter enemy, it does give some idea of the impact Hami 7 ton had on Congress, even when it chose to rebuff or harass him, throughout his more than five years in office. ${ }^{7}$

Although Thomas Jefferson rejected all of Hamilton's Federalist leanings during the 1790 's, including the need for great strength in the executive branch, in actual practice as President he developed the art of

7. Clinton Rossiter, Alexander Hamilton and the Constitution (New York, Harcourt, Brace and Wor]d, 1964), 75. 
maneuvering to pass legislation through the vehicle of his party to a high degree and did much to establish this tactic in the American system. "As the founder and leader of the first national party, Jefferson was able to dominate Congress by personal influence, and it was shown for the first time what accession of strength political management can bring to the Presidency." 8

James Young, in his book on the early days in Washington, D. C., describes Jefferson's techniques with Congress:

These, then, comprised the known inventory of presidentially improvised tools for achieving influence on Capitol Hill from 1801 to 1828: enlistment of individual members to work confidentialiy for the President from positions inside the Congressional community; enlistment of cabinet officers to work as Presidential agents from positions outside the Congressional community; personal contact with legislators through entertaining them at the executive mansion; employment of intracommunity public propoganda media, and appointment of legis lators to executive offices. 9

Jefferson's efforts and work at the time of the Louisiana purchase provide clear illustration of his techniques. Napoleon, in power in France, had laid claim to all Spanish holdings in North America, where he hoped to extend his Empire. The Spanish government, at that point little more than a puppet of her strong neighbor, had all but relinquished her entire claim to the area, although she still occupied it. Under French influence, the Spanish Intendant at New Orleans suspended the American's right of deposit without naming another site. This was in October of 1802.

8. Edwin S. Corwin and Louis W. Koenig, The Presidency Today (New York, New York University Press, 1956), 17.

9. James Sterling Young, The Washington Community 1800-1828 (New York, Columbia University Press, 7966), 178. 
As news of this move traveled up the river, the Western settlers became more and more angry. Much of their agitation was due to the fear that when France took over New Orleans, not only would the right of deposit be lost, but all use of the river as well.

The Federalists immediately seized the opportunity to win Western support away from Jefferson and his party over this issue. A. P. Whitaker, in his book The Mississippi Question vividly describes the dilemma confronted by Jefferson. On the one hand effective measures had to be taken to soothe the West. But on the other hand, strong measures might provoke war. ${ }^{10}$

Jefferson moved boldly and showed great political skill. He chose a course of action designed to silence his critics in both parties and to buy time. In the end, of course, he bought much more than time.

Federalists in Congress had demanded that the government expose all documents relating to Louisiana. This demand was countered by one of Jefferson's strongest supporters, Representative Samuel Smith of Maryland. Behind closed doors, he presented a startling resolution which proposed making two million dollars available to the President to help meet expenses of dealing with foreign nations. In effect, this would grant money to Jefferson with virtually no strings attached.

This amazing resolution, . . was an essential part of a preconceived and carefully dovetailed strategy which Jefferson had worked out with Smith and a few Republican leaders in his confidence. The West, he realized, could not be held much longer in line with mere pious resolutions and vague promises of future action: something dramatic would have to be done to keep them temporarily quiet. That something, he decided, was to send Monroe on an extraordinary mission to France, to work with or

10. A. P. Whitaker, The Mississippi Question (Gloucester, Peter Smith, 1962). 
supersede Livingston (already an envoy to France) in negotiating for a final settlement of the Mississippi question. It was obvious that nothing could be gained by talking with Spain, since France was the equitable if not already the legal owner, and Spanish moves were dictated from Paris.17

Simultaneous $7 y$, on January 11 , Smith introduced his resolution and Monroe's nomination was submitted to the Senate. Party supporters guided both through smoothiy. In France, Livingston and Monroe had instructions to attempt to negotiate the purchase of New Orleans and the Floridas. For these they were authorized to spend as much as ten million dollars. Little hope was held for the actual accomplishment of this mission, however, and the envoys had further instructions of open negotiations towards an alliance with England, if their efforts in Paris failed. The diplomatic niceties which led to France's unexpected offer to sell all Louisiana are not germane to Jefferson's relations with Congress. Suffice to say, Livingston and Monroe decided to exceed their instruction and purchase all Louisiana for fifteen million dollars. This turn of events undoubtedly surprised Jefferson as much as anyone. He had started out to buy a relatively small area at the mouth of the Mississippi, and now had purchased almost half a continent. Jefferson, from the outset had favored strict construction of the Constitution and now he must reconcile this view with the unprecedented step his administration had taken. Having decided to compromise his Constitutional convictions, Jefferson once more set about persuading the Congress to follow his lead:

Let Congress do what it has to do, he exhorted his followers, "subsilentio" and "with as little debate as possible, and par1957), 724.

11. Nathan Schachner, Thomas Jefferson (New York, Thomas Yoseloff, 
ticularly so far as respects the constitutional difficulty." The less said about it the better. Let not a day's delay intervene, lest the day for ratification pass and France thus be given the right to void the sale. Haste and silence were the watchwords. 92

Jefferson called a special session of Congress on October 17, 1803, to lay the facts before the legislators and urge their quick action. Although the Federalists tried to block the purchase, the Republicans won out. "Jefferson was following the proceeding with the keenest interest and anxiety. Overtiy, he could do nothing: but he tried to hold the sagging lines intact, and sought indirectly to overcome the recalcitrants." 13 By October 20 th the Senate had ratified the three treaties affecting the transaction and by October 28th the House had passed the necessary appropriations measures. 14

Another nineteenth century President who skillfuliy sought to maneuver legislation through Congress was James K. Polk. His activities as related in his own diary recalling the afternoon and evening of Wednesday, July 15, 1846, are indicative of his methods of persuasion:

At five o'clock P.M. my private Secreatry returned from the Capitol, and reported to me that Senator Semple of Illinois had been absent from the Senate chamber today, and that it was understood that he was packing his trunk to leave for 117 inois this evening or tomorrow morning. I immediately sent Col. Walker (the secretary) to see Judge Douglas and Mr. Smith of the Illinois delegation and get them if possible to detain $\mathrm{Mr}$. Semple to vote on the tariff bill. My information is that the fate of that bill in the Senate will depend on a single Democratic vote, and that if Mr. Semple

12. Nathan Sachner, Thomas Jefferson (New York, Thomas Yoseloff, 1957), 748.

13. Ibid., 752 .

14. Ibid., 753 . 
is absent it will probably be lost. After col. Walker left the Postmaster General called and I requested him to go and see Mr. Semple, if he had not left the city, and prevail on him if possible to remain. About sunset I learned that Mr. Semple had been at the rajlroad depot at the hour of departure of the cars this evening with his baggage, on his way to Illinois, but had been prevailed upon by Mr. Fickl in of Illinois to remain until tomorrow morning. About the same time the Postmaster General returned and reported that he had seen $M r$. Semple and requested him to call on me tonight. About eight o'clock P.M. Mr. Semple called. He showed me a letter which he had received from II Tinois stating that judgements had been recovered against him in the courts of that state for between five and six thousand dollars and that his property would be levied on to satisfy them. I made an earnest appeal to his patriotism and for the sake of the country to remain and vote on the tariff bill. After a conversation of nearly an hour he agreed to remain and vote for the bill. 15

Thus Polk used his persuasive powers to influence a vote on legislation. Here, too, it is clear that he was keeping close track of the progress of favored measures. But Polk and other strong Presidents of the nineteenth century were exceptions to the rule.

In the twentieth century Theodore Roosevelt, combining a strong personality with strong beliefs in a powerful executive, was the century's first model of the President as leader of legislation.

At no time was Theodore Roosevelt more intent on achievement, more attuned to opinion, or more conscious of the nice relationships in his own party than in November 1904 when he had at last become President in his own right. . he turned at once to fashion a program for Congress. His pursuit of the objective in that program he most valued--a measure to regulate the rail roads-demonstrated perhaps better than any other episode in his presidency. . his facility for dealing with Congress. 6

15. Allan Nevins (Ed.), Polk: The Diary of a President (New York, Capricorn Books, 1968), 124.

16. John Morton Bl um, The Republican Roosevelt (Cambridge, Harvard University Press, 1954), 73. 
Roosevelt had decided upon regulation of the railroads as "must" legislation. His efforts at securing passage of the Hepburn Bill clearly illustrate his skillful use of the bargaining power of the Presidency. Using the threat--or promise, depending on the congressman involved--of tariff reform as a ploy, he sought to change votes on the railroad question to his viewpoint. He began his negotiations with a soft line; he "consulted rather than demanded."17 As the progress of the bill slowed and stopped he took a harder line. When passage of the bill had not been secured by the end of the session in which it was introduced, Roosevelt appealed to the people in order to secure greater support for the bill.

Blum, in his biography of Roosevelt, maintains that the President employed a whole series of "calculated tactics to prepare the parliamentary environment for his railroad program." 18

Not the least of the aforementioned tactics was the actual drafting of the bill, which Roosevelt carefully supervised, using findings from the Bureau of Corporations and the Interstate Comerce Commission, as well as expert advice from lawyers and railroad men on his cabinet. The final product was calculated to contain just enough to suit his purpose and still contain nothing to alarm the marginal supporters of his program-whom he needed to secure its passage. Although it still did not satisfy Lafollette and others, all of the President's efforts were rewarded when the Hepburn act finally was passed on June 29, 1906.

Woodrow Wilson, during the first part of his Presidency, was a mas-

17. John Morton Blum, The Republican Roosevelt, (Cambridge, Harvard Uni versity Press, 1954), 78.

18. Ibid., 75 . 
terful leader of the legislative process. One outstanding example of this was his success with a currency reform program which established the Federal Reserve System. Passage of this measure came as a surprise, even to some in his own administration.

\begin{abstract}
The impossible has happened. Today, Tuesday December $23 r d$, the currency measure became Taw. The President approved it a few minutes after six o'clock in the afternoon. It was passed by a Congress dominated by the Democrats; two thirds of whom had been unsound on currency questions and a majority of whom can scarcely be said to have understood what the measure meant and would accomplish. The majority of the Republicans had also had an unenviable record on the currency. Bryan and severă 7 other members of the Cabinet had supported free silver as had the Vice President, Marsha 11, the Speaker Champ Clark and many Democratic Senators. The measure itself was the result of the labours of many men, extending over a long period, but its passage at this time in its present form was due to Woodrow Wilson, abiy supported by Glass, McAdoo and a few others. 19
\end{abstract}

Wilson was very active in seeking support for his programs and maneuvering them towards passage. In the currency reform, as in the case of the tariff bill, the President as leader of his party, continued his unrelenting pressure by argument and appea 1.20 One of the most successful of Wilson's efforts in this case was the securing of the support of his Secretary of State, William Jennings Bryan, whose influence in the Democratic party was considerable. Wilson was able to convince Bryan to compromise. Bryan then backed the President's program to the hilt. His letter in support of the bill swayed his supporters and broke the opposi-

19. David F. Houston, Eight Years with WiIson's Cabinet (Garden City, Doubleday, Page and Company, 1962), 1,90.

20. Leon H. Canfield, The Presidency of Woodrow Wilson (Rutherford, Fairleigh Dickenson University Press, 1966), 32. 
tion to the bill in the House. 21 Thus Wilson utilized party maneuvering and his own personality and persuasive power to great effect.

Another tactic often used by presidents to influence legislation is the veto. The Constitution grants to the President the power to veto bills passed by Congress with which he is in strong disagreement. From the first presidency on, the veto power has often been used in a positive way to attempt to shape legislation.

Washington vetoed only two measures. The first was entitled "an act for apportionment of representation among the several states", and sought to divide the total population of the nation by 30,000 and thus establish a House of Representatives of 120 members. Washington felt that each state's population should be divided in order for representation to be fair. For these reasons he vetoed the measure.

The second veto in Washington's administration was of a bill to change the military establishment, discharging two companies of dragoons. The President vetoed this measure on the grounds that it made no provision for paying the soldiers between the time the bill took effect and when the soldiers could be notified. In addition, Washington felt that the troops were likely to be needed on the frontier. In both instances, the President was careful to clearly state what he objected to in the measures. As Carlton Jackson states in his book on the veto:

The two vetoes helped Washington set a trend for strong executive leadership in relation to Congress. The real importance of these vetoes was not what they were about or what they said, but simply that they occurred. They set a pattern for future Presi-

21. Richard F. Fenno, Jr., The President's Cabinet (New York, Vintage Books, 1958), 191. 
dents who found the power necessary. ${ }^{22}$

One nineteenth century president who made extensive use of the veto was Andrew Jackson. Most often, his attempts to control Congress involved the veto. His vetoes tended to be vindictive and directed at specific personalities, and thus less constructive in nature than those of most other Presidents. In addition to his most famous veto, that of the National Bank, Jackson vetoed a number of internal improvement measures on the grounds that the Constitution granted no authority to Congress to appropriate funds for such projects. He thus set a pattern on the question of internal improvements which was expanded by Tyler and adopted by James K. Polk.

Polk used Constitutional reasons and financial and political expediency [the Mexican war demanded most of the resources of the Treasury and internal improvements would lead to sectionalism] . These internal improvement vetoes were Jacksonian in spirit, lacking however, the Bersonal animosity which prevailed in many of Jackson's vetoes. 23

Once again, Polk maintained a constructive approach, carefully and fulty stating his objections to the measures he vetoed.

Another nineteenth century President, Abraham Lincoln, although considered among the nation's strongest Presidents, did not depend for his strength upon ability to guide Congress. His use of power was a bit unorthodox. In prosecuting the war, he often used executive decree to

22. Carlton Jackson, Presidential Vetoes, 1792-1945 (Athens, University of Georgia Press, $19677,5$.

23. Ibid., 98 . 
accomplish his objective and then left Congress to legalize what he had done as they saw fit. 24 Lincoln's greatness lay in his ability to take decisive action in order to lead the nation through grave crisis. With respect to the veto, the unconventional nature of his use of power is further shown. In July of 1862 , Lincoln threatened to veto a Confiscation Bill because he objected to some clauses in it. The bill was still being debated and $i$ ts sponsors added an explanatory resolution denying one of the clauses to which the President objected. Lincoln signed the bill and the resolution, assuming the resolution amended the bill, which it did not. This amounted to an attempt to apply the item veto. 25

Lincoln's approach to the Presidency and Congress was unorthodox and may be explained by the extraordinary circumstances with which he dealt. His approach would not be acceptable in current times, especially in light of recent abuses of presidential power. It would seem that Lincoln's contributions to the President's role as legislative leader are minimal and Tie not in actual precedents set by him but rather in the spirit with which he approached the office--one of great strength.

When considering the use of the veto as a means of influencing Congress, another nineteenth century President stands out, if for no other reason than for the number of measures that he vetoed.

Whatever his successes or failures $\mathrm{Cl}$ eveland outdid all other Presidents in the nineteenth century in using the veto. He

24. L. H. Chamberlain, The President, Congress and Legislation (New York, Columbia University Press, T946), 12.

25. Car7ton Jackson, Presidential Vetoes, 1792-1945 (Athens, University of Georgia Press, 1967), 174. 
holds the percentage record for having vetoed more bills than any other Chief Executive. He was nonpartisan in his pension vetoes, and in most instances, despite claims to the contrary, he made no distinction between high and low ranked vetrans. Therefore, his vetoes were positive reactions. It took political courage to withstand the powerful pressures of Congressmen and the Grand Army of the Republic. 26

Eariy twentieth century Presidents made extensive use of the veto power. Most of Theodore Roosevelt's vetoes were of private bills seeking relief or a pension from the government. He vetoed eighty-two measures and only one, a bill extending the time for building a dam across the Rainy River between Minnesota and Canada, was ever overridden.

Like Cleveland, Roosevelt used the veto to fight against special privileges.

Presidents like Taft and Wilson both used the veto power to stand firmly on issues they believed in strongly. Their vetoes often evoked bitter reaction from the Congress. Both of these presidents gave careful consideration to veto messages and made constructive suggestions.

The vetoes of Harding, Coolidge and Hoover were often spectacular. "The trend toward economic relief for certain classes came dramatically to the front in the 1920's. Crusading lawmakers launched one determined attack after another to win government's favors for their constituency. With equal resolution, the Presidents stood in their way." 27 They stood firm on the issue of free trade. The three presidents' vetoes can be clustered as follows: Pensions, farm relief, government competition with private industry, general relief and Philippine independence. Hoover's

26. Jackson, 153.

27. Ibid., 187. 
vetoes were more constructive than those of Harding or Coolidge in that they did suggest compromises which he would accept.

\section{DIRECT PRESIDENTIAL APPEAL ON BEHALF OF MEASURES-- TO CONGRESS AND THE PUBLIC}

George Washington, in keeping with his overall concept of a strong President, instituted the practice of appearing before the Congress in person to deliver his messages. This practice was continued until the administration of Thomas Jefferson who chose to change the policy. Jefferson had experienced problems giving his Inaugural speech which had been criticized by the Federalists on several counts. Thus he chose to break the precedent and submit a written message to be read by the clerk to the members of Congress. He said he felt this approach would be more convenient for the Congress. The carefully drafted document was presented in January of 1802.28

Not until the Presidency of Woodrow Wilson was the practice of appearing before Congress in person reinstituted, thus strengthening the force of the executive's appeal for his program. David Houston recalls Wilson's first such appearance:

The President had to leave a twelve o'clock to go to the Capitol to read his tariff message. I had a distinct sensation when this departure was brought thus sharply to my mind. I recognized both its political and historical significance. Tuesday, April 8, 1913. Some members of the Cabinet seemed to be a trifle shaky about the venture. The President showed no sign that he was aware, as of course he was, that anything unusual was about to happen. The President regards himself as the head of its party and its political leader. He believes he can lead better, can get nearer to Congress, and convey his message more impressively to the people by delivering his message in person. He is right; and his example

28. Schachner, 693. 
will probabiy be followed till we get a President who is timid and a poor or indifferent speaker. 29

In keeping with this attitude toward the leadership of the Congress was Wilson's use of the executive office space in the Capitol Building. "Toward the beginning of his first term he frequently made use of the President's room near the Senate chamber in order to be on hand for frequent conferences with influential Senators." 30

Many presidents have used the tactic of direct appeal to the public to secure support for their programs. This was a favorite tactic of Andrew Jackson. Two events of his administration clearly illustrate his attempts to secure public support of his legislative policies. He had chosen to veto an appropriations measure for a turnpike in Kentucky, which was strong Jackson territory. James Marquis describes the veto message in his biography of Jackson:

The document relied on 01d Hickory's power over the imagination of the masses, and his uncanny ability to make his measures their measures--a phenomenon of statesmanship the country was to see much more of in the seven tumultuous years to come. Speaking over the heads of politicians and politicaliy entrenched contractors, the President addressed the people, predicating his case on the welfare of the common man. . . An appeal to patriotism was supplemented by an appeal to self-interest. The payment of the national debt would diminish taxes, the pursuit of an unrestrained internal improvement policy increase them. 31

A second event occurred under Jackson which provides interesting

29. Houston, 52 .

30. E. Pendleton Herring, Presidential Leadership (New York, Rinehart and Company, 1940), 49.

31. James Marquis, Aridrew Jackson: Portrait of a President (New York, Bobbs-Merri11 Company, 1937), 222. 
insight into his emphasis on manaing public opinion. The United States Telegraph, edited by Duff Green, had been the party "organ" and spokesman. During the early months of 1830, as the tension between Jackson and his Vice President, Calhoun, increased, the President became increasingly irritated with the Ielegraph. It seemed obvious to Jackson that Green preferred Calhoun. He decided to establish another paper. By the end of September, the Kitchen Cabinet had selected 'a candidate to edit the new newspaper. 32 The choice, which Jackson confirmed, was a relatively unknown journalist from Kentucky named Francis P. Blair. He was sent for, and by December the first issue of the new newspaper. The Washington Globe, was published. 33

Another President who frequently used the tactic of appealing directly for support of his measures to the publit was Theodore Roosevelt. This was clearly shown in his campaign for legislation to regulate railroads, as cited earlier in this chapter.

Most of the Presidents discussed in this chapter are exceptional because of the extent to which they were able to influence the course of legislation during their terms in office. The general rule in the nineteenth and early twentieth centuries was a strong Congress which tolerated little in the way of leadership from the executive and a weak President who was content not to assume a role in formulating measures or in influencing legislation. These exceptions laid the foundation for what has become the rule in the modern Presidency.

32. Marquis, 206.

33. Arthur M. Schlesinger, Jr., The Age of Jackson (Boston, Little Brown and Company, 1950), 164. 


\section{CHAPTER III}

\section{ESTABLISHMENT OF THE BUDGET BUREAU}

Congressional control of the initiation of legislative measures was virtually total at the end of the nineteenth century and in the early years of the twentieth. This control included, for the most part, appropriations bills. The accounting system, located in Congress, was intended to check up to see that the executive branch followed Congress' orders. In addition, most appropriation measures were highly detailed.

. . nearly every appropriation bill specifies to the last detail where and how the work shall be done, and the money expended;... . In other words, the problem and who are responsible for making the necessary contracts and for seeing that the work is properly done, are so restricted by the terms of the appropriation bills that all initiative and incentive to save is deadened.. . The practice in Congress of initiating appropriation bills without reference to the plans and desires of the administration, is practically a usurpation of the executive power of the President.

One chief problem of the system was the lack of any central coordination. Testimony of the sponsor of the reform legislation, Rep. Good of Iowa, clearly shows the problems of the existing system. He testified that:

Expenditures are not considered in connection with revenues, that Congress does not require of the President any carefully thoughtout financial and work program representing what provision in his opinion should be made for meeting the financial needs of the Government; that the estimates of expenditure needs now submitted

1. John T. Pratt, "An Executive Budget," The Review, I (May, 1919), 
to Congress represent only desires of individual departments, establishments and bureaus; and that these requests have been subjected to no superior revision with a view to bringing them into harmony with each other, to eliminating duplication of organization or activities, or of making them, as a whole, conform to the needs of the Nation as represented by the Treasury and prospective revenues.?

The problems were increasing rapidiy. The magnitude of government spending was increasing with the growing complexity of situations. with which government had to come to terms.

As a result of growing public concern over Federal spending, President Taft in 1909 appointed a Commission of Economy and Efficiency. The members of the commission were Frederick A. Cleveland, chairman; Frank J. Goodnow; William F. Willoughby; Walter W. Warwick; and Merritt 0. Chance. ${ }^{3}$

The Commission spent three years studying the situation and its final recommendations were broad and far-reaching. It recommended that the President prepare an extensive executive budget in advance each year, which included both proposed expenditures and expected income from revenue. In addition, they specified, this budget should be built around a plan or program which the President had for the operation of the government.

The recommendations of the Commission on Economy and Efficiency amounted to a complete turn-around in the budgeting procedure of the government. Before this time, departments and agencies had requested funds on their own initiative. 4

2. H. R. Rep. No. 362, 66th Cong., 1st Sess. 4 (1919).

3. Arthur Smithies, The Budgetary Process in the United States (New York, McGraw-Hill Book Company, 1955), 67.

4. William J. Brown, The Federal Budgeting and Appropriations Process (New York, American Bankers Assn., 1967), 2. 
The recommendations of the Commission resulted in two messages to Congress in 1912. In January President Taft stressed in a document the importance of a national budget system. In June, the Conmission sent its report, entitled The Need for a National Budget. This proposed system would serve 1) as an instrument of control for the Chief Executive, 2) as a document for Congressional action, and 3) as a basis for administration of departments and agencies in the executive branch. Despite these messages, no legislation was proposed. The Congress opposed the budget idea because many of them thought it threatened their power over expenditures. But the issue did not die. In 1916 both Republicans and Democrats included a national budget plank in their party platform. 5

The movement for budgetary reform was relatively dormant during the war years, but by 1919, with even larger increases in Federal spending, the push-was on once more. Most arguments centered around the efficiency and economy the proposed budget system would bring to the government rather than the possible strength it might give to the executive branch.

Actually, there was some discussion about the effect that the proposed legislation would have on the roles of the executive and législative branches. Most commentators seemed to feel that the reform would force upon both branches roles which were more consistent with the Constitution: "In political circles one of the chief points of discussion about the budget system is whether it will strengthen the executive or the legislative branch of the Government. It ought to strengthen both. . "6 As Henry L.

5. Brown, 2.

6. William H. Crawford, "All for Change," World's Work, XLII (August, 1921), 401 . 
Stimson wrote in 1919:

This budget must be a programme and not a mere estimate. Any clerk can make an estimate, but only the President can make a programme. Only the President can take all of the estimates which come in from the ten executive departments...., and coordinate those estimates into a single responsible and harmonious whote. . . Onty the President can decide upon the broad questions of policy upon which his administration will work for the coming year and put that programe into a shape upon which he is willing to have his administration stand for better or worse before the scrutiny of the national legislature. ${ }^{7}$

Stimson went on further to discuss the effects which he though the proposed budget reform would have on the role of Congress. He feit it was not wise for the regislature to both decide and formulate. In his opinion the man who put forth a plan should not judge its merits. 8

Reform, of course, would change all of this--the President wouid formulate and the congress would decide upon his proposals. In 1921 the two houses of Congress passed similar budget reform measures. The chief difference between the two was the location of the budget bureau. The House measure (sponsored by Representative Good) would place the bureau directly under the President. The Senate bill on the other hand (sponsored by McCormick) would follow in line with the old Hamiltonian tradition, placing the budget bureau in the Treasury Department, with less direct Presidential control. "The final 1 anguage of the act represented a victory for the Good view and a gesture toward the McCormick position." 9 While the budget bureau was to be located in the Treasury Department, the

7. Henry L. Stimson, "A National Budget System", World's Work, XXXVII (August, 1919), 529.

8. Ibid., 530 .

9. Smithies, 73 . 
director was to be appointed by the President (without Senate review) and was to be responsible directly to the President. The Budget and Accounting Act of 1921 required that the President present to Congress on the first day of every regular session:

Information concerning: (1) Permanent appropriations and expected receipts available for expenditure; (2) An account of the present condition of the Treasury; (3) Estimates of the necessary expendi tures for the Government's support during the ensuing fiscal year; and (4) Statements of the Government's expenditures and receipts during the last fiscal year and the year in progress.

The passage of the bill in effect forced the President to take a more active role in initiating policy and legislation. As W. F. Willoughby, who had served on the Taft Commission for Economy and Efficiency, and who, as a political scientist had long stressed the great need for budgetary reform stated it in an article in the Weekly Review:

For the first time in the history of the Government the President will thus be under the obligation of meeting the primary duty of a general manager of submitting to his board of directors a full and complete report of how he and his subordinates have conducted operations in the past and what, in his opinion, should be the financial and work programme of the Government in the future.11

The immediate effect of the 1921 Act upon both the executive and legislative branch was a move toward better organization and economy. The fact that the door was now open for vast expansion of the role of the President in controlling policy formation and initiating legislation to carry out that policy was not yet readily apparent. One vital indicator that

10. "System at Last", Outlook, Vo1 128 (June, 1921), 204.

11. W. F. Willoughby, "A National Budget System at Last", The Weekiy Review, IV (June 18, 1921), 575. 
things might move in this direction did come out of the Budget Bureau's first year, however. On December 19, 1921, the Director of the Bureau-Charles G. Dawes--sent out a circular to all agencies and departments (\#49) which directed that any legislative proposals initiated by executive departments or agencies, or any such proposals referred to the departments or agencies by Congressmen for approval, would have to be checked with the Budget Bureau to be sure they were consistent with the President's program.12 (If money was involved.) The circular went on:

The departments are required to inform the Congress whether or not the Bureau has found the [legislative] proposal to be "in accord with the President's program." This clearance requirement has subsequently been appiied to all departmental reports on legislation proposed by departments regardless of whether it is directly related to expenditures. 13

A7though there were such harbingers of the future role that the President would play in legislative initiation, "no significant changes occurred in the administrations of Harding, Coolidge or Hoover. "14 These Presidents were content for the most part to make general recommendations along with budget messages and leave details and actual proposals to the Congress. None of these men exerted strong pressure on Congress to pass favored measures, or made extensive use of the functions earlier discussed which are supportive of the legislative leader role.

In 1921 one of the witnesses in the committee hearings on the

12. Charles G. Dawes, The First Year of the Budget of the United States (New York, Harper and Row, 1923), 420.

13. Harold D. Smith, The Management of Your Goyernment (New York, Whittlesay House, 1945), 75.

14. Brown, 6. 
budgetary reform bill, the then Assistant Secretary of the Nayy Franklin Roosevelt, referred to the new budget system as the "entering wedge toward placing the Government on a business basis."15 It remained for Roosevelt, faced with solving the problems of the Great Depression and a World War to firmly place the Presidency in the position of strong legislative leadership. Indeed, the budget system was one "entering wedge" which he, as President, would use in part to firmly establish the Chief Executive in the position of leadership in legislative initiation and policy making.

15. Smith, 88 . 
CHAPTER IV

\section{FDR AS LEGISLATIVE LEADER}

It is to be hoped that the normal balance of executive and legis lative authority may be wholly adequate to meet the unprecedented task before us. But it may be that an unprecedented demand for undelayed action may call for a temporary departure from that normal balance of public procedure.

I am prepared under my Constitutional authority to recommend the measures that a stricken nation in the midst of a stricken world may require. These measures, or other such measures as the Congress may build out of their experience and wisdom, I shall seek, within my Constitutional authority, to bring to speedy a doption. 1

These decisive words in his first Inaugural Address foreshadowed Franklin Roosevelt's great expansion of the role of the American President and Chief Legislator. Never before had a President so broadly interpreted his legislative duty and authority under the Constitution. Roosevelt's actions as the chief source of political leadership and legislative ideas in the face of depression and war, throughout three and one-half terms in office, wrought permanent change in the institution of the Presidency. ${ }^{2}$

From the outset, Roosevelt clearly attempted to control the legislative process, in spite of opposition encountered in the Congress. During the hundred days, the first special session of Congress under his leadership, his measures were accepted and passed almost without question. As the crisis subsided, many in Congress sought to reject his leadership as

1. Franklin D. Roosevelt, The Public Speeches and Private Papers of Franklin D. Roosevelt, II (New York, Random House, 1938), 15.

2. See Mario Einaudi, The Roosevelt Revolution (New York, Harcourt, Brace and Company, 1964) for further discussion. 
vigorously as Roosevelt sought to lead. The extent to which the President was successful as legislative leader in these days, may be seen in a statement by his opposition:

Beginning with March 9, 1933, legislative history in America has been made by the recommendation and dictation of the Chief Executive and not by Congress initiating the policies and measures which have been adopted. . . So far as I can recall, since the inauguration of the New Deal on March 4, no legislation had been enacted which was not drafted by the brain trust and sent to congress from the White House with the possible exception of the Glass Banking Bill.3

In the Introduction, the President's role as chief legislator was divided into a number of usual supportive and integral functions: centralized planning of the President's program; drafting of measures within the executive branch; maneuvering of various sorts to push measures through Congress; and direct appeal to public opinion and to Congress. In all of these activities, Roosevelt became master, and many of them became firmly established functions of the Presidency during his long term in office. It will be useful to examine his Presidency in terms of these functions .

\section{CENTRAL PLANNING OF THE LEGISLATIVE PROGRAM}

As detailed in the preceding Chapter, the Budget and Accounting Act of 1921 provided for central clearance of any measures relating to appropriations through the Bureau of the Budget. In addition, early attempts were made to screen other measures and reports passing through the various departments and agencies of the executive branch.

3. Henry D. Hatfield, "Pro and Con", Congressional Digest, III (Nov., 1933), 219. 
At the beginning of Roosevelt's administration efforts were made to strengthen this centralized clearance. Within a year after taking office, Roosevelt had created the National Emergency Council, whose director was responsible for clearing al1 non-appropriations measures originating in the executive branch to be certain that they were in accord with Presidential policy.

A plan for central clearance of other types of bilis [than those involving finances] originating in administrative departments was initiated by the President in December, 1934, and was in effect through the first session of the Seventy-fourth Congress. This Plan provided that no proposal for legislation was to be submitted by any administrative department to Congress until it had been cleared through the Bureau of the Budget or the National Emergency Counci1.4

The methods by which this clearance system operated through the Executive Director of the N.E.C. are detailed in the Report of the President's Committee on Administrative Management of 1937:

A total of 170 proposals for legislation were submitted to this office in the first session of the Seventy-fourth Congress. These proposals came from eight Cabinet departments and five independent establishments and emergency agencies. Thirty-two of these measures were of such a character that the Executive Director deemed them to fall within the jurisdiction of the Bureau of the Budget. The other 138 measures were transmitted to the President, with a recommendation for disposition from the Executive Director. Thereafter, the President, in most cases, sent the measures back to the National Emergency. Council with his decision which was then transmitted by the Executive Director of the initiating department. Only after having been approved by the President were the bills in question presented to the Congress. 5

4. Edwin E. White, "The Preparation of Proposed Legislative Measures by Administrative Departments", Report of the President's Committee on Administrative Management (1937), 53.

5. Ibid., 53. 
It is interesting to note that at this time most of the major administration measures introduced at this session did not pass through this clearance machinery. ${ }^{6}$ These measures, including the Social Security Act, The Public Utility Holding Company Act, The Motor Carrier Act, The Neutrality Act, and The Soil Conservation Act nevertheless reflected directly the program of the President since he personaliy supervised their drafting and progress quite closely. 7

It was not until the Executive reorganization bill of 1939 established the Executive Office of the President and transferred the Bureau of the Budget from the Treasury Department to this office directly under the President that all of the machinery for effective central clearance finally fell into place.

The major achievement of the 1939 Act was the provision it made for an Executive Office of the President, the first in history. Forming it at first were the White House Office itself; the Bureau of the Budget, which had been transferred from the Treasury Department; the Office of Government Reports; the National Resources Board; and the Office of Emergency Management. 8

At this time the Bureau of the Budget was expanded to include an Office of Legislative Reference. This new office inherited all of the clearance functions which had formerly been performed by both the Bureau

5. White, 53.

6. Ibid., $53 f$.

7. James MacGregor Burns, Roosevelt: The Lion and the Fox (New York, Harcourt, Brace and Company, 1956), 224-262. 1957), 329 .

8. Sidney Hyman, The American President (New York, Horper and Bros., 
of the Budget and the now abolished National Emergency Council.9

\section{DRAFTING OF LEGISLATION IN THE EXECUTIVE BRANCH}

From the outset, the executive branch was active in the drafting of bills under Roosevelt. According to James MacGregor Burns' account of the first special session--the hundred days--called by FDR:

Orignially he had planned for Congress to adjourn after enacting the first set of bills, then reassemble when permanent legislation was ready. But why not strike again and again while the mood of the country was so friendly? The leaders were willing to hold Congress in session; a host of presidential advisors were at work in a dozen agencies, in hotel rooms, anywhere they could find a desk, drawing up bilis. 10

One vitally interesting aspect of Roosevelt's expansion in this area is the "host of presidential advisors" mentioned above. Before the New Deal there had been little to attract promising young men to Government Service. Now suddenly, they were drawn by the score because the government was doing something vital in society. These young men had experienced the depression and felt strongly that something vital must be done.

Most of these men were lawyers, and in the early years their activities focused around Thomas Corcoran. A graduate of Harvard, Corcoran was originally recommended to Roosevelt by Felix Frankfurter.

Thomas Corcoran and [another young lawyer] Benjamin Cohen gathered around them a brilliant group of young lawyers. Corcoran organized this team and placed men in key agencies. . He knew the law and the Constitution, was a master of legal technicality and artifice

9. Further documentation and clarification of the change-over may be found in Roosevelt's papers and in an article by Fritz Morstein Marx (see bibliography).

10. Burns, Roosevelt: The Lion and the Fox, 168. 
and had unique ability to direct operations of a team, was singleminded in his determination to get things done and never slept. More than this he had an extravagent personal charm which served as a cloak for his boundless talents as a manipulator.

These young advisors gradually came to serve as more than just masters at drafting legislative proposals and expanded their efforts to work at all stages of the legislative process, with a multitude of techniques for pushing measures through. 12

From the beginning they set to work to draft measures that were both in line with Roosevelt's plans and sound in a technical sense:

[On Apri7 26, 1933] The President asked for the passage of the National Industrial Recovery Act. He had planned to delay this legislation until his advisors could agree, but Congress was clamoring for action. A bill drafted by Senator Hugo Black of Alabama to spread work and purchasing power by reducing the work week to thirty hours had al ready passed the Senate. Unless he acted, Roosevelt would lose control of the legislative process to those who were more radical than he. Hastily, his advisors drafted the legisiation. 13

Still another early example illustrating the legal knowledge and expertise of these young men occurred when the first draft of the Securities Bill prepared by Houston Thompson was practically wrecked. Moley sent for Frankfurter to rewrite it. Felix Frankfurter brought Professor Landis, Ben Cohen and Thomas Corcoran from Harvard University. They drafted a law that was so air tight that a team of Wal1-Street Corporation lawyers

11. Arthur M. Schlesinger, Jr., The Age of Roosevelt: The Politics of Upheaval (Boston, Houghton, Miffl in and Company, 1960), 147.

12. This expansion is treated later in this chapter in the section on maneuvering and the Fair Labor Standards Act.

13. Jackson, Presidential Vetoes, 56. 
couldn't find a loophole in it. 14

As Roosevelt's administration progressed, and his troubles with the courts over legislation began, the drafting skills of his young advisors became all the more vital. Roosevelt was the first President to make wide use of such advisors for the purpose of drafting legislative proposals but the practice is now an important part of the institution of the Presidency.

\section{MANEUVERING BY THE EXECUTIVE BRANCH TO SECURE PASSAGE OF FAVORED MEASURES}

This function, it will be remembered, included three areas: patronage and party maneuvering; use of "legislative specialist" in the executive branch and actual or threatened use of the veto. All of these were much expanded and widely used by Franklin Roosevelt.

Effective handling of appointments in the early months of Franklin Roosevelt's first term contributed to his dominance of Congress and occasionally enabled him to ianore certain interest group relationships and pressures. 15

One example occurred in 1933 when he was able to secure the passage of the Economy Act, including a measure to reduce Veteran's payments in spite of strong opposition by the Veteran's organizations.

Effective use of patronage can be of great use to any President in terms of having influence over the Congress early in his term when there are many new jobs to distribute. An unusual aspect of the Presidency of

14. Arthur M. Schlesinger, Jr., The Age of Roosevelt: The Coming of the New Deal (Boston, Houghton, Mifflin Company, 1959), 442.

15. David B. Truman, The Governmental Process (New York, Alfred B. Knopf, 1955), 427. 
Franklin Roosevelt was the length of time for which he was able to use patronage as an effective tool.

The immense extension of government service under President Frankl in Roosevelt has not only been a direct cause of his great hold on Congress; its growth has also been a cause of the Republican bitterness. It is natural to expect presidential influence to decline when the jobs have been distributed. But Roosevelt's policies have resulted in the creation of new agencies with large patronage almost continuously through the administration of two terms. Under these circūmstances, exploitation of the differences between the president and his supporters in Congress has been a far more difficult matter than it usually is. 16

Closely related to this use of patronage by Roosevelt is what Louis W. Koenig terms "the art of Congressional gratification" at which he maintains Franklin Roosevelt was a master. Koenig defines this art as "giving out the easy first name, the warm handshake, the contagious smile, the intimate joke, the air of concern, the quasi-confidential interview, the picture snapped at the White House desk, the headline in the hometown newspaper. 17

Still another tactic widely used by Roosevelt may be termed party maneuvering. He was in fact the leader of his party and used that position often and we1l. Even in areas such as rules governing Congressional procedure he made his influence felt. One example of this was the amendment to the liberal discharge rule in the House. This liberal rule had been voted on in 1931 by the new Democratic majority and required only 145 signatures on a petition to force a vote on bringing a measure out of committee.

16. Harold J. Laski, The American Presidency (New York, Harper and Brothers, 1940), 141.

17. Louis W. Koenig, The Chief Executive (New York, Harcourt, Brace and World, Inc., 1968), 147. 
During the New Deal, the Democrats were hounded by this liberal rule which was serving as a tool for special interest groups. In the 74 th Congress the Democratic Teaders decided it was time for a change.

In spite of Republican opposition, the Democrats were successful in changing the rule to require a majority of house members to sign such a petition. "The rules were altered by a vote of 243 to 165 . . . The House jeaders were bent upon greasing the legislative machine for those measures dear to the heart of the chief executive." 18

Roosevelt became masterful at controlling the members of his party in both houses of Congress. More attention will be given to his skill when the progress of two legislative measures initiated by the executive branch will be traced in detail.

One unique technique, with respect to maneuvering legislation, which Roosevelt perfected was the use of special administration personnel who were "specialists" in the area of legislation. These experts came out of the group of young-lawyers discussed in the earlier-part of this chapter. They were active from the start of F.D.R.'s first term in drafting measures. Gradually the scope of their role increased until in some cases they assumed responsibility for securing the passage of administration measures as well. The role played by these men will be clearly seen in the later discussion of the passage of the Fair Labor Standards Act.

The final maneuvering tool used by Roosevelt in negotiating to have his way with the Congress was the use, or threatened use, of the veto.

More vetoes were given by Franklin D. Roosevelt than by any other 18. E. Pendleton Herring, Presidential Leadership (New York, Rinehart and Company, 1940), see pages 34-36 for discussion of this vote. 
American President. His rejections numbered 631, which put him 48 above Cleveland's total. . . Of great importance to Roosevelt, perhaps greater than the veto itself, was his threat to use it unless Congress sent him bills he could approve. He constantly gave party leaders his views on certain pending legislation, letting them know unequivacably whether he would approve or veto. once, in 1934, he suggested that the Congress withdraw an immigration bill from presidential consideration by a concurrent resolution of recall. Thus, through the veto and threat of it, Roosevelt wiel ded executive power over the Congress. 9

\section{DIRECT APPEAL ON BEHALF OF MEASURES - -}

TO CONGRESS AND THE PUBLIC

Franklin Roosevelt excelled in the art of carefully paving the way for his measures through his addresses to Congress and also through frequent appeals directly to the public. Edgar Robinson, in his work on Roosevelt's leadership, discusses these appeals. He points out that Rooseveit's theory of the Presidency centered around the masses of people whom he stated were his first concern. Going to them directly via radio to explain what he was doing and why he was doing it fit well with his style and he was very persuasive. Robinson goes on to point out that Roosevelt used another pattern when appealing to Congress:

For the Congress there was, in fact, another pattern--in addition, it is true, to a gesture of cooperative understanding. The President, in facing the Congress, was acutely aware that many in his audience were not to be persuaded, and with them he was not disposed to argue. He could and did present his case, but even in the most aggressive mood he always preserved the gentleman's acceptance that his listeners too had constituents. 20

Roosevelt's personality gave a certain style to both types of appeal

19. Jackson, 205.

20. Edgar Eugene Robinson, The Roosevelt Leadership 1933-1945 (New York, J. B. Lippencott, 1955), 158 . 
which was unique to his administration. But his frequent and skillful use of this direct approach to both the public and Congress over the period of over three terms in office made such appeals the expected task of all future presidents. Some, of course, have performed it better than others.

\section{ROOSEVELT AS LEADER OF LEGISLATION: THE FAIR LABOR STANDARDS ACT}

"One of the most important programs of the New Deal was its attempt to protect the interests of wage earners, especially those who did not have the protection of labor unions in collective bargaining, through the establishment of national minimum wages and maximum hours."21

In September of 1936, Roosevelt decided on a comprehensive minimum wage and maximum hour bill to present to the Congress. His own party was badly divided over the proposed court-packing plan to overcome the roadblocks to the New Deal represented by the Supreme Court decisions. He hoped to pull them together in support of the labor legislation. Frances Perkins, his Secretary of Labor, described the measure: "His approval was given to a draft which included the principles of the bill Gregory had prepared for me plus various theories suggested by other persons. All were in a lengthy measure drafted by Tom Corcoran and Ben Cohen."22

In May of 1937 bills were introduced in both houses and Roosevelt sent a message urging favorable consideration of the legislation. The bill was sponsored in the Senate by Hugo Black, chairman of the Senate Labor Committee.

21. Rowland Egger and Joseph P. Harris, The President and Congress (New York, McGraw-Hi11, 1963), 56. 1946), 256 .

22. Frances Perkins, The Roosevelt I Knew (New York, Viking Press, 
In the House the bill was sponsored by William P. Connory of Massachusetts, chairman of the Committee on Labor. He was enthusiastic for the legislation. He readily agreed with Senator Black, chairman of the corresponding committee in the Senate, to expedite consideration of the bill by the unprecedented step of conducting joint hearings. 23

Roosevelt had thus attempted from the outset to prepare a favorable climate for quick enactment of the legislation. But the odds began piling up against the bill in spite of his best efforts.

The lobbies of business and industry were, of course, expected to oppose the bi11, and those expectations were not disappointed. It was anticipated that labor unions, on the other hand, would support the legislation. This expectation was disappointed, because while both the Congress of Industrial Organizations and the American Federation of Labor were in favor of the legislation of labor standards, they could not agree on the version of the legislation they would support. 24

The C.I.0. gave wholehearted support to the administration version, but many leaders in the $A$. F. of $L$. opposed the idea of a minimum wage because they felt that a minimum tended to become a maximum.

A version of the bill, much reduced in scope, passed the Senate, but the measure was hopelessly mired in the House. The death of Representative Connory was a blow. Connory was replaced as committee chairman by another Representative favorable to the legislation, Mary Norton. She succeeded in getting the bill out of her committee, only to have it bog down in the Rules Committee. There it remained until Congress adjourned.

The President then called Congress back into special session. This served to focus the attention of the country on the issue,

23. Perkins, 257.

24. Egger and Harris, 58. 
and to emphasize the importance on the legislation the President delivered a series of radio addresses explaining the benefits the bill would confer. 25

Once again, however, the measure bogged down in the House. After a struggie, with opposition encountered among the southerners, the bill was recommitted to the Labor Committee and in effect killed.

By early 1938 some New Dealers had given up hope that any wagehour bill could pass through Congress. . . But the President was determined to press for the bill. Angry though he was about Southern desertions from the measure, he reluctantly ceded a northsouth wage differential in the bill to gain Southern votes. He sounded out the AFL on the price of its support. 26

Rooseveit had a new measure drafted which was shorter. He felt that the original measure had been too lengthy. A redraft by Gerard Reilly of the Labor Department boiled the measure down from forty pages to about ten. At the same time, Frances Perkins hired a young lawyer, Rufus Poole, from the Interior Department to do nothing but know all about the bill and its daily progress. 27

His resourcefuiness and adaptability had a great deal to do with getting a wage-hour law upon the books. He started a one-man hunt to find out the precise objections to the bill and by whom they were held. By canvassing scores of Congressmen he ascertained specific objections, and eventually he knew a large dependable body who would be favorable. Ultimately he could predict with reasonable accuracy the vote for or against any amendment. 28

25. Egger and Harris, 62.

26. Burns, Roosevelt: The Lion and the Fox, 342.

27. Perkins, 261 .

28. Burns, Lion and the Fox, 342 . 
Stalled in the House Labor Committee were two measures: the White House bill, with the North-South differential inserted and an AFL bill which contained no differential. Chairman Norton held the committee in session until they finally reported out the AFL version.

Wi thout the North-South differential, this measure was again hung up in the Southern dominated Rules Committee. It became clear that a discharge petition would be required to get the bill before the House for consideration but there was some concern as to whether enough signatures could be obtained on such a petition.

In this extremity the administration resorted to a crafty political maneuver. Senator Claude Pepper, a staunch Roosevelt man, was engaged in a slam-bang race for renomination in Florida. To many observers, Pepper's chances did not seem too good, but the White House had reliable information that Pepper would win. It was reasoned that if Pepper could be induced to speak vigorously for the wage-hour bill during the campaign, his later victory would be interpreted as a test of sentiment on the bill in the South. At least $\$ 10,000$ was turned over to Pepper's campaign managers by Roosevelt's assistants, who had got the money from a radio corporation executive on the basis of another deal.

The strategem worked. On May 3 Pepper won a decisive victory. Three days later the discharge petition was opened for signatures. So many representatives swarmed around the "honor roll" that House signatures reached the necessary 218. On May 24, after a tumultuous session lasting twelve hours, the House passed the bill by a heavy vote. 29

Al though the House passage of the measure was a victory for Roosevelt, the bill was much different than the Senate version passed the year before. Thus Roosevelt's backers had to continue the struggie in the conference committee which was set up to iron out the differences between the two measures.

This committee "spent three weeks reconciling the House and Senate

29. Egger and Harris, 64. 
versions, and the bill was signed. The President had been successful in getting a fair labor standards act out of Congress. " 30

Clearly, this example illustrated Roosevelt's mastery of many of the aspects of the President's role as legislative leader including central planning of a measure, drafting the measure--and in this case redrafting--all sorts of political and party maneuvering, including the preparation of a climate for a bill and the tactic of Senator-Pepper's election, the calling of a special session to emphasize the importance he placed upon the measure, the use of radio messages, bargaining with Congress and interest groups, and the use of an administration specialist, Rufus Poole, to monitor the progress of the bill in Congress.

\section{ROOSEVELT AS LEADER OF LEGISLATION} LEND LEASE

Once he had won re-election to his third term, Roosevelt turned his full attention toward the war in Europe. He felt that the United States must aid-the allies against Hitler, even at the risk of American involvement in the war. For if Hitler should take over Europe, then there was little doubt that America could be his next target and war would then be inevi table.

Roosevelt conceived lend-lease as a means to aid the British quickly wi thout a later hassle over re-payment such as had occurred after World War 1. The lend-lease bill was introduced to the Congress in January, 1941.

30. James MacGregor Burns, Roosevelt: The Soldier of Freedom (New York, Harcourt, Brace, Jovanovich, T970), 43. 
Much had gone into the preparation of the measure.

The bill itself--happily given the number H. R. 1776--vested sweeping powers in the President to make or provide "any defense article for the government of any country whose defense the President deems vital to the defense of the United States;" to sell, transfer, exhange, lease or lend any such article to any such government; to repair or outfit any such defense article for any such government; the President would also have full authority over. . . terms. 31

Robert Sherwood, in his book about Roosevelt and Harry Hopkins, his closest personal advisor during the war years, discusses the great efforts in the executive branch before the lend-lease bill was ever introduced to the Congress. Sherwood describes the drafting of the measure in the Treasury Department following lengthy groundwork by Treasury personnel on the British Economic situation. At the same time the War Department had also been working on the problem of possible aid to England. "An old statute of 1892 had been dug out of the files, whereby Congress authorized the Secretary of War to lease Army property "where in his discretion it will be for the public good." 32

Roosevelt realized from the outset that all of his skill as legislative leader would be required to get lend-lease passed. He went to the people immediately, seeking their support first. On December 16, 1940, he held a press conference on Lend-lease. In this conference he used the analogy that lend-lease for Britain was like loaning one's neighbor a length of garden hose when his home was on fire. 33

31. Robert E. Sherwood, Roosevelt and Hopkins (New York, Harper and Brothers, 1948), 228.

32. Sherwood, 225.

33. Ibid., 227 
Shortiy after this press conference, Roosevelt went on the air with a Fireside Chat. He intended to explain to the American people the grave seriousness of the situation in Europe. During the course of this "Chat" he referred to the United States as the last "arsenal of democrary" - a phrase which really caught on with the American public. ${ }^{34}$

In Congress, the battle lines were drawn. The isolationists, particularly in the Senate, were strongly led by such men as Hiram Johnson of California, Gerald P. Hye of North Dakota and Robert Taft of Ohio. The Foreign Relations Committee, which had to pass on the measure before it could be considered on the floor was firmly in isolationist hands.

Roosevelt knew that he had the votes in the House committee and in the House itself, but to make doubly sure he readily agreed late in January to accept several amendments, including a limitation of the period during which he could authorize agreements; a requirement that he consult with service chiefs before sending defense materials abroad; and a vague anti-convoy provision. On February 8 the House passed the revised bill, almost intact, 260 to 165.35

As expected, the real battle was waged in the Senate. In committee hearings the opposition was loud, headed by Joseph Kennedy and Charles Lindbergh. Roosevelt's men agrued the case for lend-lease. Then as an ace in the hole, Wendell Willkie, whom Roosevelt had just defeated at the polls, returned from a visit to England and spoke in favor of the measure before the comittee.

By mid-February the bill had been endorsed by the Foreign Relations Committee. Now one last attempt was made by the isolationists to stall the bill on the floor of the Senate. Finally, in March, Roosevelt agreed to

34. Burns, Soldier of Freedom, 46 .

35. Burns, 43. 
ałlow an amendment giving Congress final authority over appropriations and the measure was passed. By March 11, 1941, lend-lease was 1aw.

Once again, in this example, Roosevelt took the initiative in lawmaking, drafting the measure in the executive branch, preparing the way in Congress, bargaining and maneuvering to get it passed quickly, appealing to the public for support, and of course, closely monitoring its progress throughout.

From the beginning Franklin Roosevelt had siezed the initiative in lawmaking and had gradually expanded and firmed the role of the President as chief legislator. The fact that he maintained and built this role throughout more than three terms in office meant that his successors had little choice--the role of chief legislator had become an accepted and expected part of the American Presidency. 


\section{CHAPTER V}

\section{THE TRUMAN ADMINISTRATION}

Harry S. Truman was swept unexpectedly into the Presidency when F.D.R. died during his fourth term in office. At first Truman was cautious in his dealings with Congress. He used none of Roosevelt's forceful tactics and "limited himself to making recommendations in general terms, leaving Congress to work out the specifics unguided by Executive recommendations." 1

Gradually Truman's attitude toward Congress changed. After his surprise re-election in 1948 he became more forceful and aggressive-though not often successful--in his efforts to lead Congress. Even before his re-election, as will be shown later in this chapter, he managed to get Congress to adopt the Marshall Plan despite incredible odds.

This chapter will examine all of the previously discussed supportive functions and activities of the legislative leader role with respect to the Truman administration and will demonstrate that Truman to some degree performed them al7. In addition, his administration further institutionalized these functions, making it impossible for his successors not to perform them. As in the preceding chapter, one piece of legislation will be followed from its beginning to a successful conclusion, to give a view of Truman's overall approach to the legislative functions of the presidency.

1. Louis W. Koenig, The Chief Executive (New York, Harcourt, Brace and World, 1968), 140. 


\section{CENTRAL PLANNING OF A PROGRAM AND DRAFTING MEASURES IN THE EXECUTIVE BRANCH}

While these two functions supportive of the President's role as legislative leader have been treated separately in earlier chapters, it serves well to treat them together at this point. For under President Truman (and to a greater degree under Eisenhower) these functions became an institutionalized part of the Presidency and became centralized in the Office of Legislative Reference in the Bureau of Management and the Budget. Richard Neustadt has traced in some detail the circumstances which brought about this centralization and institutionalization.

The great number of public needs and demands at the end of World War II caused Truman to present to the Congress an inventory of needed legislation. By 1948 Truman refined this inventory to a rather detailed bill of particulars. At this time he instituted the practice of restating parts of the administrative program which had been introduced previously but had not been acted upon. He continued this practice on an annual basis as pressures for action from an increasingly complex nation continued. "Moreover, in the process of recurrent use of the practice of presenting annual programs acquired a momentum and survival power of its own, each year more nearly built into the institutional arrangements and expectations of Congress, agencies and presidential staff alike."i2

The 1946 inventory was included in Truman's message to Congress in September of 1945 . The message outlined both a postwar reconversion pro-

2. Richard Neustadt, "Presidency and Legislation: Planning the President's Program", American Political Science Review, Vol 49 (December, 1955), 1002. 
gram and a comprehensive statement of what later became known as the Fair Deal. ${ }^{3}$ Truman outlined at least sixteen different areas where he urged that legislative action be taken.

The actual drafting of legislation in the Truman administration took place both within the various executive departments and in the office of Legislative Reference. In 1948 this office began to coordinate the drafting of administration measures, as Neustadt recounts:

Executive Office "working teams" came into being with "7eadership" assigned to the White House, Budget or the Economic Council as the case might be, while the Legislative Reference office served as secretariat and stimulator of them al1. Each unit of the presidential staff contributed its experts and its points of view; all agencies concerned were called on to confer. A high proportion of the Fair Deal's later measures were worked out in detailed form through this new application of "coordination". . . . On many lesser proposals, . . the budget's Legislative Reference Staff led similar excursions on its own, sometimes merely tinkering with agency submissions, sometimes re-doing the whole drafting job around the conference table. ${ }^{4}$

Obviously, the development of such a specialized staff of experts could not help but further entrench the functions of drafting and central clearance within the executive branch.

\section{MANEUVERING BY THE EXECUTIVE BRANCH TO SECURE PASSAGE OF FAVORED MEASURES}

This function it will be recalled, includes such tactics as patronage

3. Harry S. Truman, The Truman Administration--Its Principles and Practices (New York, New York University Press, 1956), 148.

4. Richard Neustadt, "Presidency and Legislation: The Growth of Central Clearance", American Political Science Review, Vol. 48 (December, 1954), 662 . 
and party maneuvering and the actual or threatened use of the veto power to influence legislation. Truman had strong feelings of Party loyalty and felt that Party members in Congress had the responsibility to carry out the platform of the Party. He also felt that they seldom did so:

Only that national candidate, the President, can translate a platform into actionable terms. There are few chairmen of Congressional conmittees who follow the platform and President's construction of it more than 50 per cent of the time, and this is very bad. The chairman should be the right arm of the administration in an orderly government by party. 5

As the above would indicate, Truman's relations with the Congress were usually less than amiable. Throughout his term in office his favored domestic measures failed to get through Congress. "In fairness it should be noted that Congress responded well to Presidential leadership in foreign affairs, as the Marshall Plan and aid to Greece and Turkey attest." 6 This was due to a number of factors, including, of course, the climate of the Cold War which made action seem imperative in many instances.

Truman did employ several traditional "maneuvering" techniques to good advantage. Among these was the practice of assigning top-level assistants to hold conferences with key legislators in the office of the Secretary of the Senate to advance favored measures, and he himself frequently took part by telephone in the negotiations.

Another tactic Truman often used to good advantage was that of calling Congress into special session. Louis Koenig describes Truman's use of this technique:

5. Truman, 250.

6. Joseph S. Clark, Congress: The Sapless Branch (New York, Harper and Row, 1964), 102. 
A minor weapon in the President's legislative armory is his power to call Congress into a special session and, in so doing, to specify the legislation on which he deems action necessary. Mr. Truman was unusually successful in exploiting the technique of leadership and of political dramatization. In a move that was probably unprecedented he declared in a speech at the Democratic convention in Philadelphia, accepting the presidential nomination in July, 1948, that he would call the Republican controlled Congress into special session that very month to take action on, among other things, civil rights. His vigorous course and the contrasting inaction of Gongress, worked to his political profit in the ensuing election.

Truman's use of the veto power was vigorous and positive. His messages were usually long and gave detailed reasons for his decisions. His Taft-Hartley veto message is a good example. It lists many serious inequities which he saw in the measure, as the following excerpt demonstrates.

The bill would deprive workers of vital protection which they now have under the law. [he lists six specific cases] The bill would establish an ineffective and discriminatory procedure for dealing with major strikes affecting the public health or safety, and the bill raises serious issues of gublic policy which transcend labor-management difficulties.

Thus Truman used the veto power in a manner which gave direction and leadership to the Congress in terms of the kind of legislation which was acceptable to the President, specifically spelled out.

7. Corwin and Koenig, 89.

8. Barton J. Bernstein and Allen J. Mathison, The Truman Administration: A Documentary History (New York, Harper and Row, 1966), 124. 


\section{DIRECT APPEAL ON BEHALF OF MEASURES-- TO CONGRESS AND TO THE PUBLIC}

Truman's messages to Congress were sometimes sent to the hill and sometimes delivered in person. They were typically forceful, long and made specific demands for action.-A special message sent to Congress on February 2, 1948, on behalf of civil rights legislation serves as an example. In that message Truman asked the Congress to pass legislation in ten specific areas which were carefully detailed in the message. ${ }^{9}$

Truman felt that these specific kinds of appeals to Congress were the President's responsibility. "To him the task included dotting the ' $i$ 's' and crossing the 't's'. Advocacy in specific terms was his conception of appropriate initiative."10 As discussed earlier, this particular message relating to civil rights was pointing out where Congress had failed to act--he had asked for most of these measures before.

President Truman did not have Roosevelt's touch when it came to eliciting the support of the public--but it was a tactic he often used, and sometimes to good advantage. The 79 th Congress, the first with which Truman dealt as President, rejected almost all of the Fair Deal measures proposed by his administration. The President responded by going to the people in a radio speech on January 4, 1946:

Now I intend no blanket criticism of the Congress. Devoted and far-seeing men in both the Senate and the House have labored to make effective a program adequate to our needs. But if they are

9. Bernstein and Mathison, 104.

10. Richard E. Neustadt, Presidential Power (New York, John Wiley and Sons, Inc., 1960), 177. 
to succeed, they must be reinforced by you--the people they represent. And let me make it clear that when I speak of bills not getting any action, it is not the Congress as a whole which is responsible. . . . It is the committees which hold up action on bills. . often a bare majority of a committee - -a handfui of men--can prevent a vote by the whole Congress.

Throughout his administration, such appeals to the public to put pressure on Congress were a common Truman tactic. Another good example of this is the following excerpt from a speech he delivered in Washington on May 17, 1952. The Congress was currently considering a measure to give states the rights to offshore oil drilling. In this case, President Truman vigorousiy opposed passage of the measure:

- . I can see how the members of Congress from Texas and California and Louisiana might like to have the offshore oil for their states. But I certainly can't understand how the members of Congress from the other forty-five states can vote to give away the interest the people of their states have in this tremendous asset. It's just over my head and beyond me how any interior Senator or Congressman could vote to give that asset away. I'm still puzzled about it. As far as I am concerned, I intend to stand up and fight to protect the people's interest in this matter. ${ }^{12}$

True to his promise, Truman vetoed the measure when it passed both houses of Congress and came across his desk.

\section{TRUMAN AS LEADER OF LEGISLATION--THE MARSHALL PLAN}

Probably the single most remarkable legislative accomplishment of the Truman administration was the passage of the Marshall Plan for European recovery in 1948. The outlook for the adoption of any sort of major

11. Truman, 251.

12. Truman, 147. 
administration program was bleak, to say the very least. 1948 was an election year. Truman was considered by most (both in and out of his party) as a lame duck. The Democratic Party had lost control of both houses of Congress for the first time in fourteen years. Truman had recently vetoed two of the Republican's most favored measures. And finally, the mood of the nation was isolationist in nature at the time. Only by the most skillful use of his position and the few assets that he had was Truman able to accomplish the remarkable feat of maneuvering the Marshall Plan through the Congress.

Probably the biggest asset that Truman and his administration had in this case was the Secretary of State, George Catlett Marsha11, originator of the idea and co-author of the plan. Richard Neustadt describes Marshall and his value:

In 1947, two years after V-J day, General Marshall was something more than Secretary of State. He was a man venerated by the President as "the greatest living American," literally an embodiment of Truman's ideals. He was honored at the Pentagon as an arctiitect of victory. He was thoroughly respected by the Secretary of the Navy, James $V$. Forrestal, who that year became the first Secretary of Defense. On capitol hill, Marshall had an enormous fund of respect steming from his war record as Army Chief of Staff, and in the country generally, no officer had come out of the war with a higher reputation for judgement, intellect and probity. ${ }^{3}$

A second major factor in Truman's favor was the timing and sequence of events. In June of 1947, Secretary of State Marshall spoke at the commencement ceremony at Harvard University. His speech outlined the great problems and difficulties of European recovery and more or less sent up a trial balloon about how U.S. aid might be used to help the

13. Neustadt, 48. 
situation. Marshall's proposal was pretty general in nature and aid to the "free" nations was "directed not against any country or doctrine, but against hunger, poverty, desperation and chaos."14

Response to Marshall's speech in Europe was immediate. He had voiced an idea in general terms. The British Foreign Secretary, Ernest Beven is sometimes credited as the co-author of the Marshall Plan. He "siezed on Marshall's Harvard speech and organized a European response with promptness and concreteness beyond the State Department's expectations." 15

Another series of events which greatly helped the climate in the U.S. revolved around the actions of the U.S.S.R. under Stalin. Marshall had not wanted to push the idea of a communist menace in Western Europe. In fact, the original idea was to include Russia in the plan. As it turned out, the Soviets did not want inclusion, and in fact their actions caused the "communist menace" idea to develop and appear realistic. This greatly strengthened support for the plan in the United States.

When the Europeans met in Paris, Molotov walked out. After the Czechs had shown continued interest in American aid, a communist coup overthrew their government while Soviet forces stood along their borders within easy reach of Prague.

The third, and perhaps the most powerful factor in the Marshall Plan success was the help of the senior Senator from Michigan--Republican Arthur H. Vandenberg. After twenty years in the Senate, he was the senior

14. Bernstein and Mathison, 259.

15. Neustadt, 50 .

16. Ibid., 51 . 
member of his party. Because he had been carefully cultivated by both Roosevelt and Truman, he was a major proponent of bipartisanship in Foreign Policy and considered himself its symbol. "Moreover, by informal but entirely operative agreement with his colleague Taft, Vandenberg held the acknowledged lead among Senate Republicans in the whole field of international affairs."17 The Senator was involved by the administration early in the game in 1947. Truman called a meeting on September 29 at the White House to discuss the idea of aid to Europe. Included at the meeting were the Secretary and Assistant Secretary of State, the Secretaries of Commerce and Agriculture and legislative leaders including Vandenberg. 18

It should be remembered that 1948 was an election year. In 1947 Vandenberg was talked of as a possible Presidential candidate. Truman at this point was not, as the Democrats were casting about for a replacement.

On November 17, Truman called a special session of Congress to consider interim aid to Europe until a long range plan could be formulated. Vandenberg had insisted upon this dual approach to the situation. Even though the actual plan had not yet been formulated, Vandenberg expressed misgivings about its chances on November 18.

. . If the resistance which is showing up to the little short range European relief bill. . . is any criterion, our friend Marshall is certainly going to have a helluva time down here on the hill when he gets around to his long range plan. Its going to be next

17. Neus tadt, 51 .

18. Harry S. Truman, Memoirs: Vol. II - Years of Trial and Hope (Garden City, Doubleday and Company, Inc., 1956), 717. 
to impossible to keep any sort of unpartisan climate in respect to anything. Politics is heavy in the air. 19

Toward the end of November, Vandenberg received the report of the Harriman Commission--a State Department report which he had requested. After this he seemed much more encouraging: "The preparations that the State Department had made for this next showdown are amazing. I have never seen better work. Indeed, they have simply overwhelmed us with documentation." 20

On December 19, 1947, President Truman asked the Congress to pass the regislation needed for the Marshall Plan. His message outlined briefly the economic plight of Europe and the political and economic future which might result if Europe could not achieve freedom from fear and want under free and democratic governments. His message ended thus:

The next few years can determine whether the free countries of Europe will be able to preserve their heritage of freedom. If Europe fails to recover, the peoples of these countries might be driven to the philosophy of despair--the philosophy which contends that their basic wants can be met only, by the surrender of their basic rights to totalitarian control.

The President made his request to Congress. In the meantime, the nation was heading toward a presidential election. On New Year's day in 1948, Senator Vandenberg wrote party leaders in Michigan that he did not wish to be a presidential candidate. As recounted by the editor of his

19. Arthur H. Vandenberg, The Private Papers of Senator Vandenberg (Boston, Houghton, Miffl in Company, 1952), 379.

20. Bernstein and Mathison, 384 .

21. Vandenberg, 384 . 
Private Papers, the Senator described his reasons this way:

\begin{abstract}
"I am confident that I can best serve my country by completing my present term in the Senate," he wrote. This did not halt those who sought to advance Vandenberg as the party candidate. But the letter did strengthen Vandenberg's position as a bipartisan foreign policy leader because it represented withdrawal from a very partisan fight over the Presidency. It was timed perfectly ${ }_{2}$ coming just as the Marshall Plan debate began in the Congress.22
\end{abstract}

Vandenberg conducted the hearings on the plan before the Senate Foreign Relations Committee. The hearings were very thorough. Everyone who requested a hearing was heard. The hearings were held between January 8 and February 5, 1948. Vandenberg's own account reveals that at this point some Republicans in the Senate were about to balk. Once again the Senator's private papers revealed not only this but that such a group of Senators was meeting regularly. "Some of the group admittedly were out to 'gut' the program; others sought to 'strengthen it'. All had the Senator's ear. Some 'revisions' he could accept, thus whittling away at the opposition before it reached the floor."23

The next stumbling block, also overcome by Vandenberg, was the huge 17 billion dollar figure in the bill. Vandenberg felt that this was an unnecessary addition, and that opposition would "crystallize" around it. Accordingly, he sought to convince Marshall and the President that a better plan would be to request a generalized authorization which could be renewed each year as needs were re-assessed. This was common practice for programs which carried on over a period of years. The administration

22. Vandenberg, 385.

23. Ibid., 385 . 
agreed to his proposal. 24

Actually, Vandenberg's Foreign Relations Committee had re-written much of the measure which they reported out favorably. As the Senator said, "It is the final product of eight months of more intensive study by more devoted minds than I have ever known to concentrate on one objective in a11 my 20 years in Congress." 25

By the beginning of Apri1, 1948, the Marshall Plan was passed, signed and ready to take effect. Truman was well-pleased with the results. He fully acknowledged Vandenberg's contribution in smoothing the way. ${ }^{26}$ Truman's own contribution to the passage of the Marshall Plan is major, according to Richard Neustadt. In his account of the events, he credits Truman with careful use of the few advantages available to him:

So far as the record shows, the White House did not falter once in firm support of the Marshall Plan. Truman backed his Secretary's gamble on an invitation to all Europe. He made the plan his own in a well-timed speech to the Canadians. He lost no opportunity to widen the involvements of his own official family in the cause. . . Besides, the President continually emphasized to everyone in reach that he did not have doubts, did not desire complications, and would foreclose all he could. Reportedly, his emphasis was felt at the Treasury, with good effect. And Truman was at special pains to smooth the way for Vandenberg. The Senator insisted on "no politics" from the Administration side; there was none. [Neustadt lists reports from the administration, frequent consultations and changes in the bill as aids to the Senator.] When, finally, Vandenberg desired a Republican to head the new administering agency, his candidate, Paul Hoffman was appointed despite the President's own preference for another. 27

24. Vandengerg, 385.

25. Ibid., 391 .

26. Truman, Memoirs: Vo1. II, 119.

27. Neus tadt, 52-53: 
The Truman administration then, furthered the trends set by Roosevelt in the realm of legislative leadership. Truman performed all of the functions of legislative leader. In addition, under his administration the functions of central clearance and drafting were further entrenched in the executive branch. 


\section{CHAPTER VI}

\section{DWIGHT DAVID EISENHOWER}

General Dwight D. Eisenhower was elected to the Presidency in 1952, the first Republican following twenty years of Democratic administration under Roosevelt and Truman. As pointed out in the introduction to this work, Eisenhower considered the presentation of a legislative agenda to Congress by the President to be a usurpation of that body's powers. Both circumstances and Congressional expectations made him realize that this prerogative had indeed become the President's. His military background, coupled with a desire for precise organization and dislike of decision making caused many of the President's legislative functions--especially central clearance, planning and drafting in the executive branch--to become firmly entrenched in the institution of the Presidency during his two terms in office. As will be demonstrated, Eisenhower, as had Truman, performed all of the functions of legislative leader to some degree.

\section{CENTRAL PLANNING OF THE LEGISLATIVE PROGRAM}

Eisenhower and his staff--which he picked carefully--were cautious, careful and well-organized. Even after the transition between Truman and Eisenhower the machinery for clearance through the Legislative Reference was soon running quite smoothly.

Combined with their inexperience, the continuity of problems confronted the White House with two needs, sharply felt: the need for facts about the past to help project decisions about the future and the need for caution in commitments until homework had been 
done. The Budget clearance system proved a handy instrument in both instances.

There had been sharp reaction from Congress and the public because the President had failed to present an organized program--as had been Truman's custom--in 1953 when he first took office.

Eisenhower's own personality dictated something about how the already existing machinery was used. $\quad$ The President hated being caught without all of the facts. Thus on July 30,1953 , he sent a letter to all cabinet officers. (One month earlier, the Budget director had sent out a call for information.) Eisenhower's "letters asked for substantive ideas appropriate to the State of the Union Message, these ideas to be based on a 'thorough rethinking of the mission of your department and the ... means to achieve it." 2

By October, messages were flowing in at a considerable rate.

Cumulatively, it was an astonishing response, at least to those White House-staffers disinclined toward executive initiatives in legislation. For here were departmental declarations of intent to sponsor 1iterally hundreds of measures, great and sma 11, most of which the President waş being asked to make his own by personal endorsement in a message. 3

This really marks the end of the last attempt by a President not to perform as legislative leader. Eisenhower did present a program and endorse measures in 1954 and in every year after that. And he took a

1. Richard E. Neustadt, "The Presidency and Legislation: The Growth of Central Clearance", American Political Science Review, Vol. 48 (1954), 667.

2. Richard E. Neustadt, "The Presidency and Legislation: Planning and the President's Program", American Political Science Review, Vol. 49 (1955), 985.

3. Ibid., 985. 
vital interest in how many of his measures fared. Here, from the Congressional Quarterly, is the breakdown of Eisenhower's proposals from 1954 to 1957 and the approval rate: 4

\begin{tabular}{cccc} 
Year & $\begin{array}{c}\text { Number of } \\
\text { Proposals }\end{array}$ & $\begin{array}{c}\text { Number Passed } \\
\text { by Congress }\end{array}$ & Approval Rate \\
\cline { 3 - 4 } 1954 & 232 & 150 & $64.7 \%$ \\
1955 & 207 & 96 & $46.3 \%$ \\
1956 & 225 & 103 & $45.7 \%$ \\
1957 & 206 & 76 & $36.9 \%$
\end{tabular}

The fact that such records of the President's effectiveness as legislative leader had begun to be kept seems highly indicative of the extent to which this role had become institutionalized in the American system!

II. DRAFTING LEGISLATION IN THE EXECUTIVE BRANCH

Under Eisenhower, drafting an administration bill was a lengthy process, usually accomplished after much research, many discussions, seminars or brain-storming sessions of the Cabinet and staff members. A detailed account of this process will be found later on in this Chapter in the section on the Civil Rights Legislation of 1957.

Richard Neustadt, in an article in the American Political Science Review, describes the process as it went on in all departments in 1953, prior to the final presentation of Eisenhower's program. Extensive discussion and research had preceded this phase. Departments concentrated on drafting bills so that each proposal in Eisenhower's message to Congress

4. Herman Finer, The Presidency, Crisis and Regeneration (Chicago, University of Chicago Press, 1960), 351. 
would be followed quickly by a detailed bill bearing an Administration label. Since most decisions had been made earlier, the Budget's clearance office could easily ride herd on the drafts and coordinate them with the messages scheduled by the White House. ${ }^{5}$

Here again we see what began as an informal practice in the administration of Franklin Roosevelt institutionalized to the hilt, with drafting specialists in each department and thorough clearance procedures and supervision of drafted measures all along the way.

\section{MANEUVERING BY THE EXECUTIVE TO PASS FAVORED MEASURES}

Eisenhower began maneuvering for support of his measures early in his administration. He shunned traditional political tactics for the most part, but he used some tactics all the same. Before presenting his program to Congress, he tried it out on the Republicans as he himself relates:

At a three-day conference of Republican Legislative leaders, beginning December 17, 1953, I presented the legislative program for 1954. I asked those attending this special meeting to comment on it and on the priority in which it could be pushed through Congress. By holding such a meeting I hoped to further the consolidation of the Republican party and its support of the recommendations that $I$ intended to send to the Congress. 6

Shortly after his inauguration in the Spring of 1953, President Eisenhower had sought to establish a harmonious relationship between his Administration and the Congress as a whole. He invited all members of

5. Neustadt, 992.

6. Dwight D. Eisenhower, Mandate for Change - 1953-1956 (Garden City, Doubleday and Company, Inc., 1963), 285. 
Congress--more than 500--to a series of 1uncheons. No President had done anything of this magnitude before. ${ }^{7}$

Another practice which was instituted by President Eisenhower in an attempt to maintain generally smooth relations with the Congress was that of meeting on a regularly scheduled basis with legislative leaders. These meetings were usually held each Tuesday. ${ }^{8}$

Eisenhower fully realized that in addition to maintaining good relations with Congress, it was necessary to maneuver in various ways to get votes on his measures. This is clearly seen in his own accounts of his terms in office:

To obtain desirable legislation not only required us to keep the backing of most Republicans, but also often to win Democratic votes; so we had ceaselessly to explain, persuade, cultivate the understanding and confidence that go with personal friendship, and even cajole senators and representatives. Later, when intensified measures had to be used to achieve the support I wanted, and they were, more often than not, successful. . . . Frequently I discussed with the Cabinet the many ways we might use to induce the Congress to support the administration's programs,-including the continuing cultivation of personal friendships. My conclusion was that we would have to employ every honorable and effective means at our command. 9

As mentioned earlier, Eisenhower often expressed contempt for "politics," and for using political tactics. Even so, he realized the value of such tactics, especially toward the end of his presidency, when it was more difficult to get his measures passed.

7. Robert J. Donovan, Eisenhower: The Inside Story (New York, Harper and Brothers, 1956), 85.

8. Dwight D. Eisenhower, Waging Peace - 1956-1961 (Garden City, Doubleday and Company, Inc., 1965), 432 .

9. Eisenhower, Mandate for Change, 298. 
One event, and the President's response to it, further shows his realization of political realities. In 1957 Congress cut the appropriations for the U.S. Information Agency by fifty million dollars. Eisenhower was frustrated:

Al though even some Republicans opposed U.S.I.A., I found myself in this instance, wishing profoundly that I could have a Congress controlled by my own party. In this way I could have employed the influence of patronage and its withholding, and other means normally available to a President in getting affirmative action in Congress on his proposals. 10

Another component of maneuvering by the chief executive which first began to be widely used under Roosevelt on a casual basis was the use of legislative specialists to advise about legislation and work to secure its passage. This tactic also became more or less institutionalized under Eisenhower. Eisenhower had a specially appointed Congressional liaison staff, who did nothing but fulfill this function. This staff will be discussed in more detail in the section of this Chapter dealing with Civil Rights legislation.

The final component of the maneuvering function is the use, or threatened use, of the veto power. Eisenhower's use of the veto was positive--he always made clear his feelings regarding the legislation in question and used the veto to attempt to shape the kind of legislation that he wanted passed. He was quite proud of the fact that very few of his vetoes were over-ridden by the congress. This may be seen from the following statement he made regarding a measure that he vetoed. While on a trip, he had been given a pile of bills which had passed Congress

10. Eisenhower, Waging Peace, 138. 
and needed his signature. "One of these was a reckless and wasteful 'pork barrel' public works bill which I refused to sign even though Roemer warned (correctly, it turned out) I was probably setting the stage for the first overriding of one of my vetoes in nearly seven years."11

An example of Eisenhower's positive attitude toward the veto power was his proposal of the item veto to Speaker Rayburn during 1957 budget discussions: ". . . and enactment of the item veto--the right of a President to veto a single item in a money bill sent to him for signing, enabling him to defeat pork-barrel projects tacked onto valuable legislation."12

\section{DIRECT APPEAL ON BEHALF OF MEASURES--} TO CONGRESS AND TO THE PUBLIC

An interesting elaboration on the tactic of appealing directly to Congress on behalf of his administration's measures by Eisenhower was the careful scheduling of messages to Congress to dovetail together with the introduction of administration drafted measures. For the most part, Eisenhower delivered these messages in person. In his State of the Union Message in January of 1954 he outlined specific legislation to be requested and set out dates for subsequent special messages relating to the legislative proposals. 13

Once again, President Eisenhower's personal penchant for organization totally organized one of the functions of legislative leader. Eisenhower used special messages to Congress frequently to request specific

11. Eisenhower, Waging Peace, 431.

12. Ibid., 131 .

13. Eisenhower, Mandate for Change, 286. 
legislation now. Often this tactic was successful for him. Examples of such successes are his address requesting the passage of the National Defense Education Act in January of 1958,14 and his message to Congress on Civil Rights, to be discussed later in the Chapter.

With respect to direct appeal to the public, Eisenhower used the tactic of the radio (or television) speech to appeal to the public for support on a specific measure much less frequently than either of his predecessors. It did not fit with his style, or with his concept of the office he held. But Eisenhower could be effective in this way. On August 6,1959 , he delivered a nationwide radio and television speech to elicit support for labor reform legislation. The Landrum-Griffin Act did pass that session of Congress despite strong labor opposition.

President Eisenhower did institute an interesting link with the public and the press. Most modern Presidents had held periodic press conferences. Not surprisingly, Eisenhower organized his. They were held on a regularly scheduled basis, usually once a week. He recalls making the decision to do this:

One early decision of a relatively personal and yet official nature involved my conduct of periodic press conferences. These devices for informing the public had been handled differently by each President since the practice began. I determined to hold them weekly, depending on the amount of news, my location, and my involvement with other official matters. Furthermore, we decided on an innovation: to allow verbatim transcription--and later ${ }_{5}$ television and radio tapes--of my statements and responses. 15

14. Sherman Adams, Firsthand Report: The Story of the Eisenhower Administration (New York, Harper and Brothers, 1961), 3T.

15. Eisenhower, Mandate for Change, 232. 
One thing that the President particularly disliked was being caught without the information that he needed. So his staff was organized around the weekly press conference, to be sure that he had the information that he needed. His conferences were held on Wednesday mornings at 10:30 in the Indian Treaty Room in the old Executive Office Building. Thus at 10:00 a.m. each Wednesday, he met with his press secretary, Hagerty, and with Sherman Adams. These two would go over with him in detail any questions they felt might come up. 16

\section{EISENHOWER AS LEGISLATIVE LEADER-- THE CIVIL RIGHTS ACT OF 1957}

"As the first session of the 85 th Congress passed into history, unmourned by me, it could, however, point to one real accomplishment: enactment of the first piece of civil rights legislation since 1875."17

So begins Eisenhower's account of the passage of the 1957 bill. It was an administration measure, drafted in the Justice Department and passed, after much delay, maneuvering and compromise, by a Congress dominated by the Democrats. As was the usual practice and pattern in the Eisenhower administration, the issue had long been discussed, and proposed legislation hashed over in Cabinet meetings, before any measure was introduced. In his own account, Eisenhower recalls a situation of tension, allegations of excesses on both sides and much evidence that blacks, especially in the South were in fact being systematically deprived of their most basic human civil rights. Eisenhower said most information was originally brought to

\section{Adams, 74.}

17. Eisenhower, Waging Peace, 153. 
him by his Secretary to the Cabinet, Maxwell M. Rabb. 18

As a result of his growing awareness of the problem, in his 1956 State of the Union message the President said that he had disturbing evidence that in some locations "negro citizens are being deprived of their right to vote and are likewise subjected to unwarranted economic pressures. I recommend that the substance of these charges be thoroughly examined by a bipartisan committee" 19

Meanwhile, according to Sherman Adams' account of the events, discussion of the legislation to be proposed, which had long gone on in Cabinet Meetings, continued: On March 9, 1956, at the Cabinet Meeting, discussion was held on the problems of civil rights in the South, following a report by FBI Director J. Edgar Hoover which stated that there were fewer lynchings being reported.

At the same meeting, Brownell [the Attorney General] presented a newly revised version of the original civil rights proposal. The provision for making lynching a federal offense was dropped as unnecessarily inflammatory in the light of Hoover's report. Along with the request for a bipartisan Civil Rights - Commission, the legislation asked for three laws: an extension of the law protecting the right to vote in primary elections, giving the Justice Department the choice of taking civil as well as criminal action against violators; a broadened civil rights law giving the department more choices in determining violations; a law establishing within the Justice Department a special fivil Rights Division headed by an Assistant Attorney General.20

In his March 14 press conference, Eisenhower further paved the way for legislation by explaining to the public the request for a legally

18. Eisenhower, Waging Peace, 153.

19. Ibid., 153.

20. Adams, 336 . 
constituted civil rights commission. He felt the commission must have legal authority to subpoena witnesses and compel them to testify because of Hoover's reports that blacks who witnessed violence were fearful to talking to FBI agents. 21

Further Cabinet discussion of the proposal followed. Many of the Cabinet expected great opposition and doubted the measure!'s chances in any form. As anticipated, there was strong opposition. On July 13, eighty-three southern representatives signed a manifesto against the bi11, urging a11 members in the Senate and House to join in defeating the measure. In spite of this, on July 23 a version of the bill did pass in the House by a vote of 279 to 126. "And then it died: that same day it went on to the Senate Judiciary Committee, were it never again saw the light of day." 22

Eisenhower and his Attorney General, Brownel1, were not happy at this turn of events. "In the State of the Union message on January 10, 1957, I submitted to Congress a succinct and uncomplicated civil rights request: to enact the program proposed for 1956."23

Once again, the administration measure passed the House, on June 18, 1957. This time, Senator Knowland, the Senate minority leader, who aided the administration's efforts to get the bill passed, objected to sending the bill to the Judiciary Committee, which was presided over by James 0 . Eastland of Mississippi. Knowland pointed out that consigning the bill to that committee would effectively kill it, and introduced a

21. Eisenhower, Waging Peace, 153.

22. Ibid., 154.

23. Ibid., 154 . 
motion to send it elsewhere. At this point Senator Russell of Georgia offered a point of order against Knowland's motion. The Senate vote upheld Knowland and the administration won its first major point. Also its last, for some time to come.

Senator Russell headed opposition in the Senate. With the aid of many Democrats, an amendment was proposed to grant trial by jury in contempt of court cases. The amendment was opposed by Attorney General Brownell, with the President's support. The President tried talking with Senator Russell, as he recalls:

The next day I had a long talk with Senator Russell. I assured him of my understanding of the enormity of the problems facing the South and of my anxiety to be helpful in solving them, but told him I could not yield in my purpose of protecting the citizen's right to vote. 24

In the Senate, those opposed to the measure first succeeded in amending the bill to eliminate the authority of the Attorney General to bring civil action against violators of civil rights other than voting. Next, even after a strong plea by Knowland, they were able to further weaken the bill by inserting the jury trial amendment. Thus amended, the measure passed the Senate. Eisenhower was disappointed. He felt that the bill was worthless and even considered a veto. To quote from the President's account:

For the moment the only possible action for the administration was to get out of the ensuing Senate-House Conference as much of the House bill as possible. . . my congressional liaison staff phoned and visited, pleaded and persuaded, night and day with key members of the Conaress. After the Senate action, the House refused on August $i 3$ to send the bill to the conference committee

24. Eisenhower, Waging Peace, 156. 
and to concur in the Senate amendments. The result was that the bill went for further action, if any, to the House Rules Committee. -. On the Republican side, work began on a new. . . (jury trial) provision that the judge had the right to decide whether the defendant should receive a jury trial in a criminal contempt action resulting from an infringement of the right to vote. . . Knowland, Johnson, Rayburn and Martin carried on extended negotiations. Late on the afternoon of August 23 my telephone rang. Lyndon Johnson was on the 1ine: "I can get Ervin and the others to agree to a compromise. . ." He then asked me if the administration would accept this. After a quick call to knowland and Martin, I told Senator Johnson that the compromise was acceptable. I was quick to compliment him on his successful negotiation of this compromise. 25

After the compromise, the opposition was badly weakened.- The House approved the compromise bi11. Then, after a 24-hour and eighteen minute filibuster by Strom Thurmond, the Senate approved it as wel1. Thus, after two years, Eisenhower and his Attorney General finally secured passage of a civil rights bill. It fell far short of what they hoped for, but made some progress and was acceptable to them. 26

As shown-c-learly in this series of events, Eisenhower fulfilled the role of legislative leader--drafting the measure, speaking in its behalf, maneuvering extensively for its passage and finally sioning the measure into law. As was the case with Truman, President Eisenhower not only performed the role of legislative leader, but further entrenched its function within the institution of the Presidency and the expectations of Congress and the nation.

26. Eisenhower, Waging Peace., 160-161.

27. Adams, 343. 
CHAPTER VII

CONCLUSIONS

The basic conclusion reached after looking at the Presidency in this thesis is that the functions of the legislative leader role are now an integral, accepted and expected part of the office of the Presidency. As Richard Neustadt states in his work on the Presidency:

We tend to measure Truman's predecessors as though "leadership" consisted of initiatives in economics, or diplomacy, or legislation, or in mass communication. If we measured him and his successors so, they would be leaders automatically. A striking feature of our recent past has been the transformation into routine practice of the actions we once treated as exceptional. 1

It is this very "transformation into routine practice" of the role of legislative leader with which this paper has attempted to deal. All Presidents since FDR have performed as legislative leader and have to some degree performed all functions of that role. Major differences have occurred with respect to various president's use of an effectiveness in that role. The differences lie in the personality of the man in office and the circumstances with which he is faced. For example, currently President Ford and Congress vie over the President's economic program--his proposed solution for the nation's considerable problems. The President is attempting to function as legislative leader in this case, but wi thout much success.

1. Richard Neustadt, Presidential Power (New York, John Wiley and Sons, Inc., 1960), 8. 
If we consider the role of legislative leader to have been firmly established during the administrations of Roosevelt, and further entrenched in the bureaucratic machinery of the Presidency by Truman and Eisenhower, then a very brief look at the Presidents since Eisenhower sheds some light on the types of individual and circumstantial variations in the role.

Kennedy's term in office was short. His effectiveness as legislative leader was limited. Most of his proposals were espoused and pushed through Congress by President Johnson after Kennedy's death. Both of these Presidents took a vigorous approach to the role of legislative leader. One interesting aspect of this approach was their method of soliciting votes on measures as recounted by Ralph Huitt:

Under Presidents Kennedy and Johnson, and under the immediate direction of Lawrence 0 'Brien on the White House staff, perhaps the most systematic and intensive study ever of individual congressmen!'s attitudes toward particular measures was coupled with the most detailed campaigns to win particular votes.?

John Kennedy had some experience in Congress. Johnson's experience was considerable. As majority leader in the Senate he had built up a great backlog of friends: His success in maneuvering through many proposals -particularly with respect to domestic issues--can be attributed in large measure to his experience with and feel for the ways of Congress. It would seem then, that long experience as a member of Congress would be a helpful tool in aiding a President to function effectively as legislative

2. Ralph Huitt, "Democratic Party Leadership in the Senate", The American Political Science Review, Vol. 55 (June, 1961), 344. 
leader. In 1965, Johnson was remarkably effective and successful, utilizing his own style and sense of timing to perfection. Johnson's effectiveness was later diminished greatly by the circumstances of the unpopular Viet Nam War.

The current President, Gerald Ford, also has considerable background in the House of Representatives. However, to date this experience has not enabled him to function effectively to push his measures through Congress. This brings us again to the circumstances which a President faces. Ford faces a rather unique set. He has not been elected to the Presidency, or even to the Vice Presidency by the American people. He is a Republican following on the heels of $\mathrm{Nixon}$ and facing a strongly Democratic Congress. Finally, the nation faces severe economic difficulty. Under these circumstances, even a backlog of long experience in Congress may not be of much help to the President. Looking at both Johnson and Ford, it would seem that experience in the Congress is helpful to a President as legislative leader only if the circumstances which he faces are not overwhelmingly unfavorable to his leadership.

This paper has demonstrated that the role of legislative leader has in fact become an institutionalized and integral feature of the American Presidency. The question then remains whether this shift has weakened the Congress. There are still a few who argue that it has. But most observers and political scientists agree that the move has probably strengthened both branches. The following excerpt is typical:

Although today less than half of all legislation originates in Congress, that body is still responsible for sifting, testing, and debatina a 11 legislative proposals wherever they come from and for determining the final shape of public policy. Congress 
must decide what bills are to be considered and approved and what the legislative policies of the nation are to be. The executive branch may formulate and execute-mbut the legislature determines policy and evaluates performance. ${ }^{3}$

It is this evaluation function which has been more and more important in recent times. The current congress is evaluating what the President formulates in the way of proposed legislation and apparently finding it wanting. The Congress must fully develop its power in this area, and must not fail to perform this function. It has declined as a source of legislation. But the abuses of the Nixon administration and the complexity of today's government have made the need for Congress to function in a supervisory and evaluatory capacity "crystal clear". "In an oft quoted statement, John Stuart Mill once observed that 'the proper office of a representative assembly is to watch and control the government, ' a role for which he considered it better equipped than to develop legislative proposals." 4

Lawrence $H$. Chamberlain published a study titled The President, Congress and Legislation. He had studied ninety major laws enacted between 1894 and 1946 in an attempt to determine whether credit for their passage should be given primarily. to the Congress, to the President, or both. He raised the issue of the actual origin of measures. However, it is the feeling of this author that the actual origin of the idea for a bill is not a critical factor in determining when or if it ever becomes

3. George B. Galloway, The Legislative Process in Congress (New York, Thomas Y. Crowel 1 Company, 1953), 39.

4. Ibid., 45. 
a law. Chamberlain's study was made as the President's role as legisiative leader was beginning to emerge fully. The author seemed to feel that Roosevelt was an exception and that Congressional initiative and leadership would continue in the realm of legislation. Chamberlain failed to foresee the continued emergence of the President as legislative leader which has been recounted in this thesis. Further evidence of this emergence may be found in the appendix to this thesis, where a letter to the author from the Office of Legislative Reference indicates that a large number of proposals (700-1,000 per Congress) are initiated by Executive Branch agencies. Chamberlain seemed to feel that if the President were acknowledged as legislative leader this would automatically weaken the Congress.

In recent decades Congress has not demonstrated the kind of strength and leadership which many feel it should. It is the opinion of this writer that this is not due to Presidential assumption of the legislative leader role, but rather to Congressional failure to fully assume its functions of watch and control.

None of this should be taken to mean that only the President does or should ever initiate a piece of legislation. Many measures which an administration may adopt as its own will have been tossed around in the legislative mill in one form or another for years. The Presidency in this century has shown itself to be the place for the development of legislative proposals and the locus of legislative leadership. The Congress must further consolidate its functions of watch and control. This balance seems consistent with both the Constitution and with the needs of a complex society. 


\section{A SELECTED BIBLIOGRAPHY}

Adams, Sherman, Firsthand Report, The Story of the Eisenhower Administration. New York: Harper and Brothers, Inc., 1950.

Allen, Frederick-Lewis, The Big Change. New York: Harper and Brothers, 1952.

Amlund, Arthur Curtis, New Perspectives on the Presidency. New York: Philisophical Library, 1969.

Bailey, Thomas A., A Diplomatic History of the American People. New York: Appleton-Century-Crofts, Inc., 1950.

Baker, Ray Stannard, Woodrow Wilson: Life and Letters. Vol. 5, New York: Greenwood Press Publishers, 1968.

Beard, Charles A., Economic Origins of Jeffersonian Democracy. New York: The Macmillan Company, 1915.

Bernstein, Barton J. and Matusow, Allen J., The Truman Administration: A Documentary History. New York: Harper, and Row Publishers, 1966.

Binkley, Wilfred E., President and Congress. New York: Alfred A. Knopf, 1947.

Blum, John Morton, The Republican Roosevelt. Cambridge, Mass.: Harvard University Press, 1954.

Brown, Stuart Gerry, Alexander Hamilton. New York: Washington Square Press, Inc., 1967.

Brown, William J., The Federal Budgeting and Appropriations Process. New York: Department of Economics and Research, The American Bankers Assoc., 1967.

Burns, James MacGregor, Presidential Government: The Crucible of Leadership. Boston, Mass.: Houghton Miffl in Company., 1965.

----, Roosevelt: The Lion and the Fox. New York: Harcourt, Brace and Company, 1956.

-.--, Roosevelt: The Soldier of Freedom. New York: Harcourt, Brace, Jovanovich, Inc., 1970.

Byrnes, James F., All in One Lifetime. New York: Harper and Brothers, 1958. 
Canfield, Leon H., The Presidency of Woodrow Wilson. Rutherford, New Jersey: Fairleigh Dickenson University Press, 1966.

Chamberlain, J. P., "American Budgetary Reform", The Nation, VIII (June 14, 1919), 976-978.

Chamberlain, L. H., The President, Congress and Legislation. New York: Columbia University Press, 1946.

Clark, Joseph S., Congress: The Sapless Branch. New York: Harper and Row, 1964.

Corwin, Edward S., The Constitution and What it Means Today. Princeton, New Jersey: Princeton University Press, 1958.

Corwin, Edward S. and Koenig, Louis W., The Presidency Today. New York: New York University Press, 1956.

Crawford, William H., "All for Change", World's Work, XLII, (August, 1921) $401-408$.

Cuntiffe, American Presidents and the Presidency. London: American Heritage Publishing Co., Inc., 1968.

Dawes, Charles G., The First Year of the Budget of the United States. New York: Harper and Brothers Publishers, 1923.

deGrazia, Alfred and Schlesinger, Arthur M., Jr., Congress and the Presidency: Their Role in Modern Times. American Enterprise Institute for Public Policy Research, 1967.

Donovan, Robert J., Eisenhower: The Inside Story. New York: Harper and Brothers, Publishers, 1956.

Dunbar, Charles F., "Some Precedents Followed by Alexander Hamilton", Quarterly Journal of Economics, III, Harvard University (1889), 32-59.

Egger, Rowland and Harris, Joseph P., The President and Congress. New York: McGraw-Hill Book Company, Inc., 1963.

Einaudi, Mario, The Roosevelt Revolution. New York: Harcourt, Brace and Company, 1959 .

Eisenhower, Dwight D., Mandate for Change - 1953-1956. Garden City, New York: Doubleday and Company, Inc., 1963.

----, Waging Peace - 1956-1961. Garden City, New York: Doubleday and Company, Inc., 1965.

"Federal Budget", The Survey, XLII (June 7, 1919), 408. 
Fenno, Richard F., The President's Cabinet. New York: Vintage Books, 1958.

Finer, Herman, The Presidency: Crisis and Regeneration. Chicago, I11.: University of Chicago Press, 1960.

Galloway, George B., Congress At the Crossroads. New York: Thomas Y. Crowel1 Company, 1946.

-.--, The Legislative Process in Congress. New York: Thomas Y. Crowe 11 Company, 1953.

Garfield, James A., "A Century of Congress", Atlantic Monthly, XL (JuTy, 1877), 49-64.

Gross, Bertram M., The Legislative Struggle - A Study in Social Combat. New-York:-McGraw-Hith Book Company, Inc., 1953.

Harlow, Ralph V., The History of Legislative Methods in the Period Before 1825. New Haven, Conn.: Yale University Press, 1917.

Hart, James, The American Presidency in Action - 1789. New York: The MacMil1 an Company, 9948.

Hatfield, Henry D., "Pro and Con", Congressional Digest, Vol. 12 (Nov., 1933), 261-283.

Hayden, Ralston, "Two P.lans for a National Budget", Review, Vol. 2 (May $15,1920), 513-515$.

Hendrick, Burton J., Lincoln's War Cabinet. New York: Little, Brown and Company, 1946.

Herring, E. Pendleton, "American Government and Politics", American Political Science Review, Vol. 27 (June, 1933), 404-422.

----, "Executive-Legislative Responsibilities", American Political Science Review, Vol. 38 (Dec., 1944), 1153-1165.

-.--, Presidential Leadership. New York: Rinehart and Company, 1940.

Hoover, Herbert, The Ordeal of Woodrow Wilson. New York: McGraw-Hill Book Company, Inc., 1958.

Houston, David F., Eight Years With Wilson's Cabinet. Garden City, New York: Doubleday, Page and Company, 1962. (2 Vol.)

Huitt, Ralph, "Democratic Party Leadership in the Senate", The American Political Science Review, Vol. 55 (June,1961), 333-345.

Hyman, Sidney, The American President. New York: Harper and Brothers, 1954. 
Hyman, Sidney, "What is the President's True Role?", New York Times Magazine, (September 7, 1958 17.

Ickes, Harold L., The Secret Diary of Harold Ickes. New York: Simon and Schuster, 1954. (3 Vol.)

Inaugural Addresses of Presidents of the United States from George Washington 1789 to John F. Kennedy - 1961. Washington, D. C.: U. S. Government Printing office, 1961.

Jackson, Carlton, Presidential Vetoes, 1792-1945. Athens, Ga.: University of Georgia Press, 1967.

James, Dorothy Buckton, The Contemporary Presidency. New York: Western Publishing Company, Inc., 1969.

James, Marquis, Andrew Jackson: Portrajt of a President. New York: Bobbs-MerritT Company, 1937.

Kimmel, Lewis H., Federal Budget and Fiscal Policy: 1789-1958. Washington, D.C.: The Brookings Institution, 1959.

Koenig, Louis W., The Chief Executive. New York: Harcourt, Brace and World, Inc., 7968.

Laski, Harold J., The American Presidency, An Interpretation. New York: Harper and Brothers, 1940.

Leuchtenburg, William Edward, Franklin Roosevelt and the New Deal - 19321940.- New York: Harper and Row, 1963.

Lodge, Henry Cabot, Al exander Hamilton: American Statesman. New York: Houghton-Mifflin and Company, 1893.

Marx, Fritz Morstein, "The Bureau of the Budget: Its Evolution and Present Role"., The American Political Science Review, Vol. XXVIX (No. 4 and No. 5), 653-684 and 689-698.

McGuire, 0. R., "Administrative Lawmaking", Annals of the American Academy of Political and Social Science, Vol. 85 (May, 1936), 73-84.

Milton, George Fort, The Use of Presidential Power: 1789-1943. Boston, Mass.: Little, Brown and Company, 1944.

Mitche11, Broadus, Alexander Hamilton: The National Adventure 1789-1804. New York: The Macmillan Company, 1962.

Morison, Elting E., The Letters of Theodore Roosevelt. Cambridge, Mass.: Harvard University Press, 1951.

Morris, Richard B. (Ed.), Alexander Hamilton and the Founding of the Nation. New York: The Dial Press, 1957. 
Neustadt, Richard E., "The Presidency at Mid-Century", The Presidency. Boston, Mass.: Little, Brown and Company, 1969.

---., "The Presidency and Legislation: The Growth of Central Clearance", American Political Science Review, Vol. 48 (1954), 641-671.

--.-, "The Presidency and Legislation: Planning the President's Program", American Political Science Review, Vol. 49 (1955), 980-1021.

-..-, Presidential Power. New York: John Wiley and Sons, Inc., 1960.

Nevins, Allan (Ed.), Polk: The Diary of a President. New York: Capricorn Books, 1968.

Payne, Will, "Your Budget", Saturday Evening Post, Vol. 192 (January 3, 1920), 30-32.

Perkins, Frances, The Roosevelt I knew. New York: Viking Press, 1946.

Pratt, John T., "An Executive Budget", The Review, Vol. I (May 31, 1919), 55.

Randa11, James G., Constitutional Problems Under Lincoln. Urbana, I11.: University of Il7inois Press, 1964.

Robinson, Edgar Eugene, The Roosevelt Leadership 1933-1945. New York: J. B. Lippencott and Company, 1955.

Roosevelt, Franklin D., The Public Papers and Addresses of Franklin D. Roosevelt. New York: Random House, (Vo1. I) 1938, (Vol. II) 1938; (Vol. III), 1941.

Roosevelt, Theodore, An Autobiography of Theodore Roosevelt. New York: Charles Scribner's Sons, 1958.

Rossiter, $\mathrm{Cl}$ inton, Alexander Hamilton and the Constitution. New York: Harcourt, Brace and Wortd, 1964.

----, The American Presidency. New York: Harcourt, Brace and World, 1956.

Schachner, Nathan, Thomas Jefferson. New York: Thomas Yoseloff, 1957.

Schlesinger, Arthur M., Jr., The Age of Jackson. Boston, Mass.: Little, Brown and Company, 1950.

----, The Age of Roosevelt - The Coming of the New Deal. Boston, Mass.: Houghton-Mifflin Company, 1959.

---., The Age of Roosevelt - The Politics of Upheaval. Boston, Mass.: Houghton-Mifflin Company, 1960. 
Sherwood, Robert E., Roosevelt and Hopkins. New York: Harper and Brothers, 1948.

Smithies, Arthur, The Budgetary Process in the United States. New York: McGraw-Hil1 Book Company, Inc., 1955.

Stimson, Henry L., "A National Budget System", The World's Work, Vol. XXXVIII, (August, 1919), 371-375.

Stoke, Harold W., "Presidential Coordination of Policy", Annals of the American Academy of Political Science, Vol. 221 (May 1942), 101-i07.

Syrett, Harold C., and Cooke, Jacob E., (Eds.), The Papers of Alexander Hamilton, Vol. VI, December 1789-August 1790. New York: Columbia University Press, 1962.

"System At Last", Outlook, Vol. 128 (June 21, 1921), 203-204.

Thatch, Charles C., The Creation of the Presidency 1775-1789. Baltimore, Md.: The Johns Hopkins Press, 1922.

Truman, David B., The Governmental Process. New York: Alfred A. Knopf, 1955.

Truman, Harry S., Memoirs: Vo1. II: Years of Trial and Hope. Garden City, New York: Doubleday and Company, 1956.

----, Mr. President. New York: Farrar, Straus and Young, 1952.

-.--, The Truman Administration: Its-Principles and Practices. New York: New York University Press, 1956.

Vandenberg, Arthur Hendrick, The Greatest American: Alexander Hami 7 ton. New York: G. P. Putnam's Sons, 1927.

----, The Private Papers of Senator Vandenberg. Boston, Mass.: Houghton, MiffTin and Company, 1952.

Wann, A. J., The President as Chief Administrator. Washington, D. C.: The PubTic Affairs Press, 1968.

Whitaker, A. P., The Mississippi Question 1795-1803. Gloucester, Mass., 1962.

White, Edwin E., "The Preparation of Proposed Legislative Measures by Administrative Departments", Report of the Presidents Comittee on Administrative Management. Washington, D. C.: United States Government Printing Office, 1937.

Willoughby, W. F., "A National Budget System at Last", The WeekTy Review, Vol. 4 (June 18, 1921), 575-576. 
Wilson, Woodrow, Constitutional Goyernment in the United States. New York: Columbia University Press, 1908.

Young, James Sterling, The Washington Community 1800-1828. New York:

Columbia University Press, 1966. 
APPENDIX 


\section{SEP 1 \& 971}

Miss Patricia M. Springer

2141 S.E. Oak

Portland, Oregon 97214

Dear Miss Springer:

This is in reply to your letter of July 20 asking for certain information concerning proposed legislation initiated by the executive branch. I am sorry the reply is late because of the press of other work and hope that the information provided will be of some assistance to you in your project.

Attached is a table showing the number of public and private laws enacted in each Congress since the 73rd. These figures include many proposals which were initiated by the executive branch agencies, but it is nct possible for us to identify how many were so initiated.

We also have data available which indicate that, since the 82 nd Congress, the executive branch agencies have initiated legislative proposals which range from $700-1,000$ per Congress, with the average per congress being about 830 .

The executive branch does not transmit appropriation bills as such. The President transmits an annual budget at the beginning of each calendar year and submits changes to that budget during the course of each year in the form of budget supplementals or budget amendments. After hearings, the Appropriations Comittees report numbciz:-1 appropriation bills; there are usually not more than 20 appropriation bills enacted by the Congress each year.

sincerely,

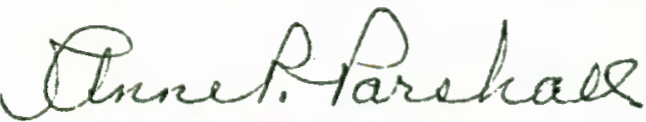

Anne P. Parshall

Special Assistant to the Assistant Director for Legislative Reference

Enclosure 
Presidential action on legislation enacted by Congress follows:

\begin{tabular}{|c|c|c|c|c|c|c|c|}
\hline & Congress & $\begin{array}{l}\text { Public } \\
\text { law }\end{array}$ & $\begin{array}{l}\text { Private } \\
\text { law } \\
\end{array}$ & Total & Vetoed & $\begin{array}{l}\text { Over- } \\
\text { ridden }\end{array}$ & $\begin{array}{l}\text { Became } \\
\text { law w/o } \\
\text { signature }\end{array}$ \\
\hline $\begin{array}{l}\text { :esident } \\
\text { Roosevelt }\end{array}$ & $\begin{array}{l}73 \mathrm{rd} \\
74 \mathrm{th} \\
75 \mathrm{th} \\
76 \mathrm{th} \\
77 \mathrm{th} \\
78 \mathrm{th}\end{array}$ & $\begin{array}{r}540 \\
985 \\
919 \\
1,005 \\
850 \\
568\end{array}$ & $\begin{array}{l}436 \\
737 \\
840 \\
657 \\
635 \\
589\end{array}$ & $\begin{array}{r}976 \\
1,722 \\
1,759 \\
1,662 \\
1,485 \\
1,157\end{array}$ & $\begin{array}{r}72 \\
147 \\
115 \\
165 \\
82 \\
46\end{array}$ & $\begin{array}{l}1 \\
1 \\
3 \\
0 \\
0 \\
2\end{array}$ & $\begin{array}{l}0 \\
0 \\
0 \\
0 \\
0 \\
2\end{array}$ \\
\hline $\begin{array}{l}\text { :es. Roosevelt to } \\
\text { l/12/45 } \\
\text { :es. Truman to } \\
1 / 2 / 46\end{array}$ & $\int_{1}^{1} 79 t h$ & 733 & 892 & 1,625 & $76 *$ & 0 & 1 \\
\hline esident Truman & $\begin{array}{l}80 \text { th } \\
81 \text { st } \\
82 \text { nd }\end{array}$ & $\begin{array}{l}906 \\
921 \\
594\end{array}$ & $\begin{array}{r}457 \\
1,103 \\
1,023\end{array}$ & $\begin{array}{l}1,363 \\
2,024 \\
1,617\end{array}$ & $\begin{array}{l}75 \\
79 \\
22\end{array}$ & $\begin{array}{l}6 \\
3 \\
3\end{array}$ & $\begin{array}{l}0 \\
2 \\
1\end{array}$ \\
\hline $\begin{array}{l}\text { 'esident } \\
\text { Eisenhower }\end{array}$ & $\begin{array}{l}83 \mathrm{rd} \\
84 \mathrm{th} \\
85 \mathrm{th} \\
86 \mathrm{th} \\
87 \mathrm{th}\end{array}$ & $\begin{array}{r}781 \\
1,028 \\
936 \\
800 \\
885\end{array}$ & $\begin{array}{r}1,002 \\
893 \\
784 \\
492 \\
684\end{array}$ & $\begin{array}{l}1,783 \\
1,921 \\
1,720 \\
1,292 \\
1,569\end{array}$ & $\begin{array}{l}52 \\
34 \\
51 \\
44 \\
20\end{array}$ & $\begin{array}{l}0 \\
0 \\
0 \\
2 \\
0\end{array}$ & $\begin{array}{l}0 \\
0 \\
0 \\
0 \\
0\end{array}$ \\
\hline $\begin{array}{l}\text { esident Kenneãy } \\
11 / 22 / 63 \\
\text { esident Johnson } \\
10 / 3 / 64\end{array}$ & $\begin{array}{l}\text { to) } \\
\text { to) } 88 t h \\
\text { to }\end{array}$ & 666 & 366 & 1,026 & $9 * *$ & 0 & 0 \\
\hline esident Johnson & $\begin{array}{l}89 \text { th } \\
90 \text { th }\end{array}$ & $\begin{array}{l}810 \\
640\end{array}$ & $\begin{array}{l}473 \\
362\end{array}$ & $\begin{array}{l}1,283 \\
1,002\end{array}$ & $\begin{array}{r}14 \\
8\end{array}$ & $\begin{array}{l}0 \\
0\end{array}$ & $\begin{array}{l}0 \\
0\end{array}$ \\
\hline $\begin{array}{l}\text { esident Nixon } \\
\text { s of } 8 / 18 / 71)\end{array}$ & $\begin{array}{l}\text { 91st } \\
\text { 92nd }\end{array}$ & $\begin{array}{l}695 \\
127\end{array}$ & $\begin{array}{r}246 \\
23\end{array}$ & $\begin{array}{l}941 \\
150\end{array}$ & $\begin{array}{r}11 \\
2\end{array}$ & $\begin{array}{l}2 \\
0\end{array}$ & $\begin{array}{l}2 \\
0\end{array}$ \\
\hline
\end{tabular}

* Two (2) bills were vetoed by President Roosevelt; the rest by President Truman.

** One (1) bill was vetoed by President Kennedy; the rest by President Johnson. 